\title{
La calificación de los vicios de los reglamentos ${ }^{1}$
}

\author{
Fernando López Ramón (España) \\ Universidad de Zaragoza \\ flopez@unizar.es
}

\section{NOTA BIOGRÁFICA}

Fernando LÓPEZ RAMÓN es catedrático de Derecho Administrativo en la Universidad de Zaragoza y preside la Asociación Española de Profesores de Derecho Administrativo. Profesor invitado en varias universidades europeas y latinoamericanas, cuenta con 7 sexenios de investigación, coordina el Observatorio de Políticas Ambientales y es autor de diversas publicaciones, particularmente en materia de medio ambiente, urbanismo, bienes públicos y defensa nacional.

\section{RESUMEN}

El punto de partida del estudio se encuentra en la constatación, hasta ahora no advertida, de una continuidad normativa en las sucesivas regulaciones legales de los vicios de los reglamentos. Así, cabe considerar como sorprendente la diversidad de interpretaciones doctrinales y jurisprudenciales producidas sobre tales regulaciones, pues si inicialmente dominaron las tesis graduales que admitían la misma escala de vicios en los reglamentos que en los actos administrativos (vicios no invalidantes, de anulabilidad y de nulidad de pleno derecho), finalmente han terminado por prevalecer las tesis unitarias que consideran todo vicio de un reglamento determinante de su nulidad de pleno derecho. La trascendencia de los efectos derivados de esta última postura se agudiza al comprobar el carácter inadvertido del cambio jurisprudencial experimentado en la aplicación de normas de contenido similar. Con tal base se puede concluir el estudio destacando los argumentos contextuales, históricos y finalistas que habrían de llevarnos a dar preferencia a las tradicionales tesis graduales.

\section{PALABRAS CLAVE}

Reglamentos: control judicial; Potestad reglamentaria: infracciones; Vicios de los reglamentos.

\begin{abstract}
The starting point of the article is the observation of a continuity in the successive legal regulations of the vices of the administrative regulations. It is then possible to address the diversity of doctrinal and case law interpretations produced on such regulations. Whereas it was initially admitted the same scale of vices for administrative regulations than for administrative acts (i.e. classifying vices into non-invalidating vices, vices of anullability and vices of nullity), the thesis that has prevailed is that any vice of an administrative regulation turns it null and void. The significance of such shift in the doctrine is emphasized by the inadvertent change in case-law concerning similar regulations. The article concludes by explaining the reasons that should lead us to give preference to the traditional gradual theses.
\end{abstract}

\section{KEYWORDS}

Administrative regulations: invalidity; Administrative regulations: judicial control; Vices of the administrative regulations.

\footnotetext{
1 Publicado en Revista de Administración Pública, 205, 2018.
} 


\section{SUMARIO}

1. PLANTEAMIENTO. 2. LAS ORIGINARIAS PREVISIONES LEGALES DE LOS VICIOS DE LOS REGLAMENTOS. 3. LA TESIS UNITARIA: TODO VICIO DE UN REGLAMENTO ES DE NULIDAD DE PLENO DERECHO. 4. LA TESIS GRADUAL: VICIOS NO INVALIDANTES, DE ANULABILIDAD Y DE NULIDAD DE PLENO DERECHO EN LOS REGLAMENTOS. 5. LA CONTINUIDAD NORMATIVA EN LA VIGENTE REGULACIÓN LEGAL DE LOS VICIOS DE LOS REGLAMENTOS. 6. EL CAMBIO INADVERTIDO A LA JURISPRUDENCIA UNITARIA Y LA ALARMA DOCTRINAL. 7. RECAPITULACIÓN: LOS FUNDAMENTOS DE LA VUELTAA LA TESIS GRADUAL DE LOS VICIOS DE LOS REGLAMENTOS. BIBLIOGRAFÍA²

\section{PLANTEAMIENTO}

Últimamente, se advierte cierta sorpresa doctrinal ante algunas anulaciones judiciales de planes de urbanismo por infracciones en el procedimiento de elaboración de los mismos consideradas de escasa envergadura ${ }^{3}$. La calificación de todo vicio de los reglamentos, categoría en la que se incluyen los planes, como determinante de la nulidad de pleno derecho, parece estar en el origen de esa jurisprudencia, lo que ha generado variadas reacciones críticas ${ }^{4}$.

Entre las diversas perspectivas que cabe adoptar para el análisis de los fundamentos de tan sorprendentes decisiones judiciales, en este trabajo vamos a centrarnos en el origen del problema y su evolución conforme al derecho positivo, la doctrina y la jurisprudencia, sin perjuicio de ofrecer también como contraste algunas conclusiones de los estudios sobre el derecho comparado en la materia. Nos remontamos a la formulación originaria de la cuestión, porque en ella se encuentra el planteamiento de la interpretación normativa que nos sigue ocupando en la actualidad.

La cuestión del alcance de los vicios de los reglamentos o disposiciones generales no se planteó realmente en nuestro derecho administrativo hasta después de 1958, momento en que adquirió interés como consecuencia de las previsiones legislativas que innovaron notablemente el régimen de la potestad reglamentaria. Aquí vamos a exponer el contenido de esas previsiones originales y de las que las han sustituido, a fin de constatar la continuidad normativa que, en esta materia, cabe advertir en las sucesivas regulaciones llevadas a cabo principalmente en la legislación de procedimiento administrativo de 1958, 1992 y 2015. De manera que, como veremos a continuación, el origen de las discrepancias, en el problema que nos ocupa, no se encuentra en el legislador, sino más bien en las diversas interpretaciones doctrinales y jurispruden-

2 Abreviaturas empleadas en orden cronológico:

LJ'56: Ley reguladora de la Jurisdicción Contencioso-Administrativa de 27 de diciembre de 1956 (derogada por LJ'98).

LRJ'57: Ley de régimen jurídico de la Administración del Estado de 26 de julio de 1957 (derogada definitivamente por LOG'97).

LPA'58: Ley de procedimiento administrativo de 17 de julio de 1958 (derogada por LPAC'92).

LOE'67: Ley Orgánica del Estado de 10 de enero de 1967 (derogada por la Constitución de 1978).

LPAC'92: Ley 30/1992, de régimen jurídico de las administraciones públicas y del procedimiento administrativo común (derogada por LRJ'15 y LPAC'15).

LOG'97: Ley 50/1997, de 27 de noviembre, de organización, competencia y funcionamiento del Gobierno.

LJ'98: Ley 29/1998, de 13 de julio, reguladora de la Jurisdicción Contencioso-Administrativa.

LPAC'15: Ley 39/2015, de 1 de octubre, del procedimiento administrativo común.

LRJ'15: Ley 40/2015, de 1 de octubre, de régimen jurídico del sector público.

3 Entre los casos más llamativos, cabe citar: STS 4382/2015, de 6 de octubre, ponente J. E. PECES MORATE, que declara la nulidad de pleno derecho del Plan de Ordenación del Territorio de la Costa del Sol Occidental (Málaga) por falta del informe de impacto de género, sentencia que es objeto de un interesantísimo voto particular del magistrado J. J. SUAY RINCÓN; STS 4838/2016, de 8 de noviembre, ponente R. FERNÁNDEZ VALVERDE, que anula el Plan General de Santander como consecuencia de haberse anulado previamente por el mismo TS -debido a defectos y omisiones en la evaluación de impacto ambiental- el proyecto de la obra hidráulica que completaba el abastecimiento de agua del municipio, obra que, sin embargo, al aprobarse el plan anulado ya se encontraba terminada y en funcionamiento.

4 Véanse recientemente: para los supuestos de anulación de planes de urbanismo por defectos formales, J. A. SANTAMARÍA PASTOR (2014), "Muerte y transfiguración de las desviaciones de poder: sobre las sentencias anulatorias de planes urbanísticos", Revista de Administración Pública, 195, págs. 197-215 (en especial, págs. 212-215), A. M. GONZÁLEZ SANFIEL (2017), "Límites a la declaración de nulidad del planeamiento", en F. LÓPEZ RAMÓN y F. VILLAR ROJAS (coords.), El alcance de la invalidez de la actuación administrativa, Madrid: Instituto Nacional de Administración Pública, págs. 411-459 (pág. 413) y C. TOLOSA TRIBIÑO (2017), "La impugnación de los planes de urbanismo: consecuencias de su anulación. Doctrina jurisprudencial”, Actum, Inmobiliario \& Urbanismo, 38, págs. 49-62 (pág. 49); en relación con las anulaciones de todo tipo de reglamentos, C. AGOUĖS MENDIZÁBAL (2017) “La modulación de los efectos de la invalidez de los reglamentos", en F. LÓPEZ RAMÓN y F. VILLAR ROJAS (coords.), El alcance de la invalidez de la actuación administrativa, Madrid: Instituto Nacional de Administración Pública, págs. 361-410 (pag. 362). 
ciales de unos textos normativos cuyo contenido ha permanecido prácticamente inalterado en las sucesivas reformas legales.

\section{LAS ORIGINARIAS PREVISIONES LEGALES DE LOS VICIOS DE LOS REGLAMENTOS}

En el ámbito de las reformas administrativas de la década de 1950, la potestad reglamentaria fue objeto de tres grandes novedades: la primera fue de tipo procesal al admitirse la impugnación directa e indirecta de reglamentos ante lo contencioso-administrativo en la LJ'565; la segunda consistió en establecer legalmente los límites de competencia, rango, legalidad y reserva de ley de los reglamentos en la LRJ'576; la tercera supuso una regulación común del procedimiento de elaboración de los reglamentos en la LPA'58 ${ }^{7}$. De esta manera, la potestad reglamentaria del Estado, hasta entonces objeto de escasas menciones normativas, se sujetó a un régimen jurídico integrado por las vías judiciales de control, los límites sustantivos y el procedimiento de aprobación ${ }^{8}$.

Entre esas reglas, interesa aquí destacar la relativa al alcance de la invalidez de los reglamentos, que en el art. 28 LRJ'57 se cifraba en la nulidad de pleno derecho, aunque únicamente en los casos enumerados, pues se establecía que "serán nulas de pleno derecho las disposiciones administrativas que infrinjan lo establecido en los artículos anteriores ${ }^{9}$. Posteriormente, en el art. 47.2 LPA'58 se reiteró la fórmula, de nuevo con explícita declaración de la nulidad de pleno derecho de los reglamentos en los supuestos previstos en el art. 28 LRJ' $57^{10}$.

La nulidad de pleno derecho establecida en esos preceptos, en la propia literalidad de las normas, no comprendía todas las infracciones de la legalidad que pudieran cometerse en el ejercicio de la potestad reglamentaria, sino únicamente las referidas con carácter imperativo en los "artículos anteriores» de la LRJ'57, es decir: las violaciones de la jerarquía normativa (art. 23), de la competencia y rango (arts. 24-25), de la legalidad y las materias reservadas a la ley (art. 26), y particularmente de la explícita prohibición de establecer penas, tributos o cargas de todo tipo por vía reglamentaria (art. 27).

${ }^{5}$ La primera técnica de control de los reglamentos ilegales había consistido en su inaplicación, tal como se ordenó hacer a los jueces y tribunales en la Ley Orgánica Provisional del Poder Judicial de 1870 (art. 7.1). Después se permitió el recurso indirecto contra reglamentos, permitiendo recurrir los actos administrativos de aplicación del reglamento considerado ilegal, aunque sin preverse la anulación de éste, en las Leyes de lo Contencioso-Administrativo de 13 de septiembre de 1888 (art. 3) y 22 de junio de 1894 (art. 3 ). El recurso directo contra reglamentos sólo se había admitido por el Consejo de Estado cuando aquellos contuvieran declaraciones concretas que afectaran a los interesados, a través del recurso de agravios en materia de personal previsto en la Ley de 18 de marzo de 1944 (art. 4). En la LJ'56, se permitió ya la impugnación directa e indirecta de los reglamentos (art. 39), aunque el recurso directo venía lastrado por la general exigencia de la llamada legitimación corporativa [art. 28.1.b)]. Al margen, se habían desarrollado algunas técnicas de control de las ordenanzas locales en cuyo detalle no vamos a entrar a fin de no sobrecargar todavía más la exposición.

${ }^{6}$ La LRJ'57 contenía el régimen de las disposiciones generales del Gobierno, sus comisiones delegadas, ministros y demás autoridades estatales (arts. 23-29)

7 La LPA'58, en el título VI dedicado a los procedimientos especiales, incluyó el capítulo I sobre el procedimiento para la elaboración de disposiciones de carácter general (arts. 129-132).

${ }^{8}$ Poco ha variado desde entonces el esquema general de ese régimen jurídico, cuyos elementos básicos siguen integrándose efectivamente por esos tres grandes elementos, actualmente reproducidos, según hemos de ver, en las vigentes LJ'98, LRJ'15 y LPAC'15. Sin embargo, donde sí se encuentran notables diferencias es en el alcance concreto de las técnicas, que ahora empiezan a resultar útiles para el efectivo control jurídico de la potestad reglamentaria, al resultar despejadas en su aplicación de trabas legitimadoras, interpretaciones restrictivas y fórmulas tolerantes con las vulneraciones de la legalidad por las administraciones públicas.

${ }^{9}$ Las remisiones normativas a otros preceptos, que pueden responder a un deseo de certeza jurídica, no siempre son una buena técnica legislativa, pues, en contra de la voluntad del legislador, multiplican fácilmente las incertidumbres. ¿Cuáles eran los "artículos anteriores» cuya infracción determinaba la nulidad de pleno derecho? F. GARRIDO FALLA (1963), Tratado de Derecho Administrativo, Madrid: Instituto de Estudios Políticos, vol. III (pág. 79, en nota) sostuvo que los preceptos concernidos debían ser estrictamente los dos anteriores (arts. 26 y 27 LRJ'57), por entender que «lo excepcional de la nulidad absoluta exige una respuesta restrictiva». Sin embargo, lo lógico es entender que los preceptos concernidos eran los comprendidos en el mismo epígrafe de la ley (arts. 23-27 LRJ'57). Pero aun así, a la vista de los variados contenidos de los preceptos remitidos, ¿todos se imponían con la fuerza de la nulidad de pleno derecho para caso de incumplimiento? ¿la constancia de la adopción del reglamento en el acta de la sesión del Consejo de Ministros tenía el mismo alcance que la observancia del principio de jerarquía normativa? ¿no se podía subsanar la falta de firma de una orden ministerial? ¿debíamos dar a la regulación de la firma igual significado que a la previsión reglamentaria de una sanción penal?

10 Art. 47 LPA'58: "1. Los actos de la Administración son nulos de pleno derecho en los casos siguientes: (...). 2. También serán nulas de pleno derecho las disposiciones administrativas en los casos previstos en el artículo 28 de la Ley de régimen jurídico de la Administración del Estado». 
En la nulidad de pleno derecho no estaban incluidos otros vicios, como los derivados de la infracción del procedimiento de elaboración de las disposiciones generales que, con carácter verdaderamente novedoso, se había establecido en los arts. 129-132 LPA'58. Por mera razón cronológica, si los supuestos de nulidad de pleno derecho de los reglamentos estaban ceñidos a los casos previstos en el art. 28 LRJ'57, esta ley no podía comprender supuestos regulados posteriormente en la LPA'58. Por añadidura, lógicamente cabía considerar que si todas las infracciones de la legalidad fueran constitutivas de nulidad de pleno derecho, carecería de sentido enumerar algunas, pues hubiera bastado con haber establecido la regla general.

Habría, no obstante, una forma de incluir los vicios del procedimiento de elaboración de reglamentos en la sanción de la nulidad de pleno derecho, una interpretación de los preceptos legales que permitiría llegar a esa conclusión. Se trata de una forma que, a mi juicio, implicaría torcer la finalidad de la declaración legal. Vamos a ver: el manejo en cuestión versaría sobre el alcance del principio de reserva de ley impuesto en el art. 26 LRJ'57:

"La Administración no podrá dictar disposiciones contrarias a las leyes ni regular, salvo autorización expresa de una ley, aquellas materias que sean de la exclusiva competencia de las Cortes.».

Las dos modalidades de la reserva de ley, la formal y la material, estaban comprendidas en la dicción de la norma. Así, todo lo regulado en las leyes se imponía a la Administración por su superior rango normativo ${ }^{11}$ y, además, las materias de competencia parlamentaria se excluían por completo de la potestad reglamentaria $^{12}$.

En todo caso, era el contenido sustantivo de las leyes lo que parecía imponerse en el precepto, pues se prohibía a la Administración «dictar disposiciones contrarias a las leyes». Las disposiciones no podían contrariar las leyes, es decir, lo establecido en los reglamentos no podía infringir las leyes, pero sin hacer referencia con esa expresión al procedimiento de elaboración de los mismos. En el contexto normativo de una enumeración de vicios de los reglamentos, resultaría muy extraño que justamente las reglas de procedimiento, que en 1957 todavía no estaban verdaderamente establecidas, fueran las que hubieran de acogerse bajo la fórmula genérica de lo contrario a las leyes. Por tanto, cabe sostener ya que, en la aplicación del ordenamiento jurídico, era lógico considerar que las exigencias de procedimiento establecidas en las leyes no resultaban afectadas por esa prohibición ni por la consiguiente nulidad de pleno derecho establecida en los arts. 28 LRJ'57 y 47.2 LPA'58. Cuando en la elaboración de un reglamento la Administración omitía trámites previstos en la ley (p. ej., en los arts. 128-132 LPA'58), estaba infringiendo la ley, pero no por ello el contenido del mismo reglamento resultaba contrario al contenido sustantivo de la ley. Lo cual no quería decir que las infracciones del procedimiento de elaboración de las disposiciones generales carecieran de consecuencias, sino más bien que habría de aplicarse a tales infracciones, siquiera fuera por analogía, la misma gradación de vicios de los actos administrativos, distinguiendo entre irregularidades no invalidantes, vicios de anulabilidad y vicios de nulidad de pleno derecho.

Ha de informarse también de que el mismo contenido (la reserva formal y material de ley) del antes transcrito art. 26 LRJ'57 fue literalmente reproducido en una de las leyes fundamentales del período franquista, concretamente en el art. 41.I LOE'67, estableciéndose a continuación (art. 41.II LOE'67):

«Serán nulas las disposiciones administrativas que infrinjan lo establecido en el párrafo anterior.».

La nulidad era la sanción establecida para toda violación de la reserva formal y material de ley, que se convertía, así, en la fórmula genérica que expresaba los límites legales de la potestad reglamentaria. Frente a la enumeración de vicios contenida en los «artículos anteriores» al art. 28 LRJ'57, en el art. 41 LOE'67 se optaba por concentrar la ilicitud de los reglamentos en la infracción de las leyes o en la regulación de materias de la exclusiva competencia parlamentaria.

11 Se trata de las reservas formales de ley derivadas de la simple regulación de cualquier materia por una norma de rango legal, reservas que han de desplegar su eficacia impidiendo la regulación reglamentaria mientras no se haya producido una deslegalización.

12 Estas son las reservas materiales de ley, que entonces se contenían en las leyes fundamentales y actualmente se contienen en la Constitución de 1978, para la regulación de los derechos y libertades en el art. 53.1 y para otras cuestiones de manera dispersa en su texto. Estas reservas se imponen a la Administración con independencia de si el poder legislativo las ha desarrollado o no y sin que se admita ya la deslegalización, aunque sí la delegación legislativa, salvo en las materias reservadas a ley orgánica (art. 81). 
Esa opción de la legalidad fundamental del período podía hacer variar el sentido de la prohibición dirigida a la Administración de "dictar disposiciones contrarias a las leyes», pues al no insertarse ya tal prohibición en el contexto de una enumeración de vicios (como sucedía en los arts. 23-27 LRJ'57), bien cabía entender que concentraba todas las infracciones de los reglamentos, incluyendo tanto las de tipo material o sustantivo, como las de tipo formal o adjetivo. Unas mismas palabras legales pueden, ciertamente, alterar su significado en función del contexto en el que se incluyen.

No obstante, conviene también tener en cuenta que la sanción establecida -en el art. 41.II LOE'67-para cualquier infracción de la legalidad por los reglamentos, era la nulidad («serán nulas»), sin el calificativo "de pleno derecho» que figuraba en los arts. 28 LRJ'57 y 47.2 LPA'58. En consecuencia, la nulidad podía ser absoluta o de pleno derecho en los casos previstos en esos preceptos (que remitían a la enumeración de los arts. 23-27 LRJ'57) y relativa o determinante de la anulabilidad en los demás casos.

Así pues, nuestro primer dato se resumiría en la apreciación de que en el derecho positivo de 19571958 (en vigor hasta la LPAC'92) la nulidad de pleno derecho de los reglamentos se refería a una lista de vicios, habiendo de deducirse de tal dato la posibilidad de vicios no incluidos en la enumeración legal y no determinantes, por tanto, de la nulidad de pleno derecho. La fórmula general establecida en 1967 (vigente hasta la Constitución de 1978) no modificó la situación, al limitarse a establecer, también genéricamente, la nulidad de las disposiciones contrarias a las leyes sin determinar el grado de dicha nulidad.

\section{LA TESIS UNITARIA: TODO VICIO DE UN REGLAMENTO ES DE NULIDAD DE PLENO DERECHO}

En la doctrina se sostuvieron dos líneas interpretativas muy diferentes de las normas que venimos considerando. Una fue la que vamos a denominar tesis unitaria, conforme a la cual todo vicio de un reglamento es siempre determinante de la nulidad de pleno derecho. Su más destacado valedor fue E. García de Enterría, cuyos enunciados en este punto fueron seguidos por algunos autores ${ }^{13}$.

Efectivamente, desde sus primeros e influyentes estudios sobre la potestad reglamentaria, E. García de Enterría, probablemente influido por la dogmática alemana, mantuvo la tesis de que "la sanción de la ilegalidad de un reglamento es siempre la nulidad de pleno derecho», mientras que la simple anulabilidad era la regla de las ilegalidades del acto administrativo; diferencia de régimen que el autor justificaba «en que en el primer caso se defiende la forma de constitución del ordenamiento y la pureza de éste, en tanto que en el segundo se intenta proteger la seguridad de las relaciones concretas constituidas» ${ }^{14}$.

Posteriormente, el mismo E. García de Enterría insistiría en su tesis de que «todas las ilegalidades de los reglamentos determinan en estos precisamente una nulidad de pleno derecho", razonando que si la ilegalidad de un reglamento determinase una mera anulabilidad que sólo pudiese ser hecha valer en el plazo de recurso, "se habría introducido en la economía del sistema normativo una causa nueva de derogación de las leyes formales, la derogación producida por un reglamento cuando transcurrieran los plazos de impugnación sin formular ésta». Rechazaba también que la anulabilidad procediera en ningún supuesto de vicio de forma del reglamento y ello con independencia de si el mismo se hacía valer en el recurso directo o en el indirecto, pues «el reglamento que incurre en vicio de forma infringe también una ley, la que impone el procedimiento en cuestión, aunque pueda no infringir ninguna en el plano material de sus regulaciones» ${ }^{15}$.

Tal sería la doctrina que finalmente accedió al tratamiento general de la materia en E. García de Enterría y T. R. Fernández Rodríguez, quienes consideraban que «la cuestión no ofrece, pues, la más mínima duda»:

${ }^{13}$ A través del prof. L. MARTÍN-RETORTILLO, pertenezco a la escuela que puso en marcha y lideró el prof. E. GARCíA DE ENTERRÍA, con quien tuve la suerte de compartir algunas conversaciones. Nunca en ellas advertí el más mínimo rasgo de imposición de ideas ni de criterios, pues el maestro aceptaba con naturalidad la discrepancia. Le gustaba implicarse en el debate y se mostraba dispuesto a comprender e incluso a aceptar y potenciar los argumentos ajenos cuando los encontraba fundados. Ello permite explicar que, en la materia que tratamos y en otras, los administrativistas de su escuela no siempre sigamos uniformemente sus tesis.

${ }^{14}$ E. GARCÍA DE ENTERRÍA (1959), "Recurso contencioso directo contra disposiciones reglamentarias y recurso previo de reposición”, Revista de Administración Pública, 29, págs. 161-185 (págs. 167-169).

${ }^{15}$ E. GARCÍA DE ENTERRÍA (1970), Legislación delegada, potestad reglamentaria y control judicial, Madrid: Tecnos (págs. 13-14). 
«Todo reglamento que rebasa los límites formales y sustanciales que acantonan el ámbito de ejercicio lícito de la potestad reglamentaria incurre en un vicio determinante de su nulidad de pleno derecho.» ${ }^{16}$.

Llegó así a formularse una tesis que, si bien inicialmente no fue seguida por la jurisprudencia mayoritaria, estaba destinada a configurarse como dominante en la misma jurisprudencia. Sin embargo, los argumentos manejados a tal fin ofrecen algunas dudas, acentuadas éstas probablemente por la concisión con la que aquellos fueron expresados. Vamos a tratar de exponer su sentido y analizarlos críticamente:

a) La primera razón esgrimida es la que podríamos denominar ordinamental y que se expresa en la frase antes transcrita, donde García de Enterría considera que la nulidad de pleno derecho de todo vicio del reglamento se explica por referirse a «la forma de constitución del ordenamiento y la pureza de éste». El autor contrapone los vicios del reglamento a los que pueden concurrir en el acto administrativo, donde la regla de la anulabilidad se explicaría por el intento de "proteger la seguridad de las relaciones concretas constituidas». Parece difícil, sin embargo, que la seguridad jurídica haya de circunscribirse a las relaciones ya creadas y que no afecte a las relaciones futuras, es decir, a las que han de crearse por virtud de la norma reglamentaria que las regula ${ }^{17}$. La seguridad jurídica es justamente el fundamento tradicionalmente empleado para identificar distintos grados de invalidez de los reglamentos, que justifican las limitaciones temporales y de otro tipo para su impugnación. Y ello, no solamente en la historia del derecho administrativo español, sino también en otros ordenamientos que mantienen antiguas limitaciones de ese tipo o las han introducido modernamente, como hemos de ver más adelante. En definitiva, "la pureza» del ordenamiento no exige tratar de la misma manera a los vicios de distinta trascendencia que pudieran concurrir en un reglamento.

b) El segundo argumento es el de la derogación, que parece una continuación del anterior, ya que se sostiene que la admisión de vicios de anulabilidad en los reglamentos, al impedir la impugnación de los mismos una vez transcurrido el plazo de recurso correspondiente, determinaría una "causa nueva de derogación de las leyes formales». Razonamiento que tampoco parece exacto, pues, como han destacado varios autores, la inaplicación, en la elaboración de un reglamento, de algunos trámites previstos en una ley no significa que tales trámites legales dejen de estar vigentes, habiendo de desenvolver toda su fuerza invalidatoria en la impugnación temporánea del reglamento que no los hubiere observado ${ }^{18}$.

c) El último fundamento utilizado por García de Enterría es el de la legalidad, al entender que el reglamento con vicio de forma «infringe también una ley, la que impone el procedimiento en cuestión». Por tanto, habría de entenderse que la sanción de nulidad de pleno derecho de los reglamentos contrarios a las leyes, conforme a los arts. 28 LRJ'57 y 47.2 LPA'58, comprendía infracciones sustantivas y formales de las leyes. Se plantea así finalmente, no un principio esencial del orden jurídico, sino una cuestión interpretativa del derecho positivo, la relativa a la fijación del alcance del precepto legal que prohíbe a la Administración "dictar disposiciones contrarias a las leyes». El problema queda pues notablemente rebajado en su significado, que se reduce a la interpretación de un precepto legal siguiendo las reglas de la hermenéutica jurídica. Anteriormente, al explicar el contenido de ese precepto, hemos sostenido ya que el significado textual y contextual de la norma permitía postular que las exigencias de procedimiento establecidas en las leyes no estaban afectadas por la prohibición legal ni por la consiguiente nulidad de pleno derecho. Recuérdese, en efecto, que en el art. 28 LRJ'57 únicamente se declaraba la nulidad de pleno derecho de los reglamentos que infringieran lo dispuesto en los artículos 23-27 de la propia LRJ'57, en una fórmula que se reiteró explícitamente en el art. 47.2 LPA'58 y que no comprende las reglas de procedimiento establecidas en los arts. 129-132 de la misma LPA'58. Por tanto, con apoyo en la literalidad de la norma y su contexto, cabe sostener que lo prohibido bajo sanción de nulidad de pleno derecho era dictar reglamentos contrarios al contenido sustantivo de las leyes. Lo cual no significa, como ya hemos indicado, que se permita dictar reglamentos contrarios a las exigencias de forma y procedimiento establecidas en

${ }^{16}$ E. GARCÍA DE ENTERRÍA y T. R. FERNÁNDEZ RODRÍGUEZ (1974), Curso de Derecho Administrativo, vol. I, Madrid: Civitas (pág. 147).

17 Para una crítica de la opinión de GARCíA DE ENTERRÍA, véase G. DOMÉNECH PASCUAL (2002), La invalidez de los reglamentos, Valencia: Tirant lo Blanch (págs. 224-226), quien desarrolla la función del principio de seguridad jurídica en los reglamentos (págs. 226-243).

18 Ampliamente sobre estas razones, G. DOMÉNECH PASCUAL (2001: 104-107). 
las leyes, sino simplemente que la infracción de tales exigencias se configura siguiendo la gradación de vicios que va desde la nulidad de pleno derecho para los supuestos más graves, hasta la anulabilidad e incluso las irregularidades no invalidantes en los demás casos.

Junto a los autores que siguen la tesis unitaria bajo la vigencia de la LPA'58 sin ofrecer nuevos argumen$\operatorname{tos}^{19}$, un intento de consolidar dicha tesis se debe a R. Gómez-Ferrer Morant, cuyos principales fundamentos son los siguientes ${ }^{20}$ :

a) El primero supone insistir en el razonamiento ya formulado por García de Enterría sobre el alcance de la legalidad cuya infracción determina la nulidad de pleno derecho. Estamos pues ante una cuestión interpretativa acerca de cuál deba ser el sentido que ha de concederse a la regla del art. 26 LRJ'57 ("La Administración no podrá dictar disposiciones contrarias a las leyes»). Para Gómez-Ferrer, «nada autoriza a suponer que el legislador identifica la disposición general con su contenido, prescindiendo de los demás elementos que la constituyen», de manera que, siendo la disposición general «un acto jurídico de la Administración que está constituido por diversos elementos (competencia, procedimiento, fin, contenido, forma, etc)», será "contraria a la ley y, por ende, nula de pleno derecho, cuando la vulnere en cualquiera de sus elementos». El razonamiento está muy bien expuesto, pero a mi juicio resulta parcial, pues únicamente atiende al texto del art. 26 LRJ'57, sin referir el contexto normativo en el que se sitúa, que no es una fórmula general, sino un sistema de lista. El legislador optó, en el art. 28 LRJ'57, al que se remitió el art. 47.2 LPA'58, por identificar las infracciones de la legalidad determinantes de la nulidad de pleno derecho de los reglamentos enumerando tales infracciones («serán nulas de pleno derecho las disposiciones administrativas que infrinjan lo establecido en los artículos anteriores»). La lista deja fuera lo que no incluye y difícilmente podía haber incluido en la enumeración lo que todavía no estaba regulado, es decir, el procedimiento de elaboración de reglamentos previsto en los arts. 129-132 LPA'58. Obsérvese que si el legislador hubiera querido que todo vicio de un reglamento fuera determinante de su nulidad de pleno derecho, le habría bastado con establecer, en el art. 47.2 LPA'58: "serán nulas de pleno derecho las disposiciones administrativas contrarias a las leyes». En tal caso, sí sería admisible la argumentación de Gómez-Ferrer y habría que incluir en la nulidad de pleno derecho las infracciones sustantivas y formales de la legalidad. Pero en el art. 47.2 LPA'58 lo que se estableció fue que "serán nulas de pleno derecho las disposiciones administrativas en los casos previstos en el art. 28 $L R J$ '57» y en este precepto no se contiene una fórmula general, sino una enumeración (por remisión a otros preceptos) de los «casos previstos» como determinantes de la nulidad de pleno derecho de los reglamentos, casos, hemos de insistir, entre los que no se incluye la infracción de las reglas de procedimiento establecidas posteriormente en la LPA'5 $8^{21}$.

b) A continuación, el mismo autor critica la jurisprudencia del TS que venía aplicando a los vicios de procedimiento de los reglamentos la escala de los vicios de los actos administrativos: nulidad de pleno derecho, anulabilidad e irregularidades no invalidantes. Su discrepancia deriva de considerar que, de esta manera, el TS descompone los elementos del reglamento, separando el contenido del procedimiento para darles un tratamiento diferente que rompería la unidad del acto reglamentario. Vamos a ver: la disección de los diferentes elementos de los actos a fin de aplicarles las diversas consecuencias establecidas en el ordenamiento es una operación habitual en los análisis jurídicos, dado que, por ejemplo, las reglas de competencia por razón del territorio o la materia suelen ser más exigentes que las de competencia jerárquica, procedimiento

19 Véanse: L. MARTÍN-RETORTILLO (1963), "Actos administrativos generales y reglamentos. Sobre la naturaleza de la convocatoria de oposiciones”, Revista de Administración Pública, 40, págs. 225-249 (pág. 226), quien, al repasar las diferencias existentes entre las disposiciones generales y los actos administrativos, explica que la ilegalidad de las primeras consiste en la nulidad de pleno derecho, mientras que los actos administrativos ilegales son, por regla general, simplemente anulables; R. MARTíN MATEO (1970), Manual de Derecho Administrativo, Madrid (pág. 146), limitándose a constatar que los reglamentos ilegales son nulos de pleno derecho, tanto cuando infringen los trámites exigibles, como cuando violan normas de superior jerarquía; J. BERMEJO VERA (1977), La publicación de la norma jurídica, Madrid: Instituto de Estudios Administrativos (págs. 152-153, en nota), que se declara partidario de la tesis de la nulidad absoluta de cualquier vicio de un reglamento con explícito rechazo de la tesis contraria.

20 R. GÓMEZ-FERRER MORANT (1977), "Nulidad de reglamentos y actos dictados durante su vigencia", Revista Española de Derecho Administrativo, 14, págs. 387-400 (págs. 387-393).

21 Otra cuestión que plantea el autor es la relativa a si la infracción de las leyes determinante de la nulidad de pleno derecho de un reglamento comprende también la vulneración de principios generales del Derecho, sosteniendo que tal vulneración «no puede reconducirse fácilmente a una infracción de ley» (GÓMEZ-FERRER, 1977: 392). Aun comprendiendo que se pueden plantear casos diferentes, por ejemplo, en función de si los principios generales están o no positivizados, particularmente me inclinaría por el criterio opuesto, al menos si estamos ante un verdadero principio general, de los que tienen "carácter informador del ordenamiento jurídico» en la espléndida fórmula del art. 1.4 del Código Civil, pues si el principio informa la ley, ha de entenderse que tanto se viola ésta al infringir su letra como lo que sería su espíritu. 
o forma. No hay, por tanto, en esas diferenciaciones ninguna descomposición del acto jurídico unitario, que sigue siendo el mismo aunque sus diversos elementos tengan un tratamiento normativo distinto. En realidad, lo que está haciendo en este punto nuestro autor es volver a presentar su entendimiento unitario de toda infracción de la legalidad como determinante de la nulidad de pleno derecho, cuestión hermenéutica a la que ya nos hemos referido en el apartado anterior.

c) Plantea también Gómez-Ferrer si cabría estimar que se viola el principio de proporcionalidad al caracterizar cualquier infracción del procedimiento de elaboración de reglamentos como vicio de nulidad de pleno derecho. Su respuesta es negativa por considerar que «las normas de procedimiento son garantía de legalidad, acierto y oportunidad en el ejercicio de una competencia de interés público tan relevante como la normativa, que exige una especial reflexión, evitando las improvisaciones». Difícilmente se podría discrepar de tan acertada consideración, que, sin embargo, resulta tan aplicable a la elaboración de un reglamento como a la formación de un acto administrativo. La garantía que entraña el procedimiento es un planteamiento universal, es decir, relativo a todas las actuaciones de la Administración, sean normativas o resolutivas. No obstante lo cual, en aplicación precisamente del principio de proporcionalidad, el ordenamiento puede tener en cuenta la diversa trascendencia de las infracciones de tipo formal para establecer una escala de efectos derivados de las mismas.

d) Por último, parece que el autor trata de relajar las consecuencias de la tesis unitaria al afirmar que «la nulidad de pleno derecho (del reglamento) no conduce tampoco necesariamente a unas consecuencias de extraordinaria gravedad», dado que, como es conocido, en nuestro ordenamiento "tal nulidad no se comunica de forma automática e inevitable a los actos dictados a su amparo». Estamos aquí ante una cuestión que parece simplemente opinable, por lo que ha generado criterios dispares en nuestra doctrina ${ }^{22}$. En todo caso, al margen ya de los efectos sobre los actos derivados del reglamento ilegal, difícilmente podríamos compartir en la actualidad la idea de que la nulidad de pleno derecho de un reglamento, por sí sola, carece de gravedad. Baste en tal sentido con recordar la alarma que están produciendo bastantes declaraciones de nulidad de pleno derecho de planes de urbanismo debido a su naturaleza reglamentaria en casos de ausencia de algún trámite. Por tanto, "consecuencias de extraordinaria gravedad», en este caso, las hay.

Otra defensa doctrinal de la tesis unitaria se debe a M. Fernández Salmerón ${ }^{23}$. El autor comienza planteando la nulidad de pleno derecho de todo vicio del reglamento como un dogma derivado de la circunstancia de que en la LPA'58, al igual que en la posterior LPAC'92 (y en la vigente LPAC'15), no se distinguirían tipos de vicios de los reglamentos, estableciendo siempre la nulidad de pleno derecho ${ }^{24}$. Eso no tiene que ser así en los términos normativos textuales y contextuales, como ya hemos visto, y en todo caso no lo es para las tesis graduales que cabría considerar dominantes bajo la vigencia de la LPA'58, como enseguida vamos a exponer. De ahí que interese adentrarse en los «argumentos normativos y dogmáticos» que el mismo autor expone con detalle para avalar su postura:

a) Asegura Fernández Salmerón que los vicios de nulidad de pleno derecho identificados explícitamente en los arts. 28 LRJ'57 y 47.2 LPA'58, es decir, los derivados de la infracción de los arts. 23-27 LRJ'57, agotarían los posibles vicios de los reglamentos, afirmación que le permite sostener su tesis unitaria de que todo vicio del reglamento es de nulidad de pleno derecho. Sin embargo, eso es ir más lejos de lo que la norma preveía, ya que en los arts. 23-27 LRJ'57 no se contenían todas las exigencias legales aplicables a los reglamentos. En efecto, habían de incluirse también los aspectos establecidos en otros sectores legislativos, entre los que cabe destacar el tradicional dictamen del Consejo de Estado, y los requisitos que pudieran preverse en leyes posteriores, como los trámites establecidos en la LPA'58. Así, ante la ausencia de explícita calificación legal del grado de nulidad correspondiente a estas otras infracciones de los reglamentos, enten-

22 Por ejemplo, R. PARADA VÁZQUEZ (1989), Derecho Administrativo, Madrid: Pons, t. I (pág. 67), sostiene que los radicales efectos pretendidos con la nulidad de pleno derecho de los reglamentos «no se compaginan con el mantenimiento de la validez de los actos dictados en aplicación del reglamento ilegal». Planteamiento con el que coincide L. MARTín REBOLLO (2017), Manual de las leyes administrativas, Cizur Menor: Aranzadi (pág. 407) al afirmar que «si se conservan actos de aplicación de un reglamento nulo es evidente que la nulidad queda un tanto matizada en sus perfiles teóricos».

${ }^{23}$ M. FERNÁNDEZ SALMERÓN (2002), El control jurisdiccional de los reglamentos. Procedimiento administrativo, proceso judicial y potestad reglamentaria, Barcelona: Atelier (en especial, págs. 207-221); aunque se trata de una publicación posterior a la LPAC'92, se refiere con detalle a la LPA'58, por lo que nos interesa considerarla ahora.

${ }^{24}$ M. FERNÁNDEZ SALMERÓN (2002: 209-210) asegura que, en la LRJ'57 y la LPA'58, «la sanción de nulidad era la única que nuestro ordenamiento jurídico reservaba a los reglamentos viciados, cuyo régimen de invalidez había querido separarse en todo del propio de los actos administrativos», conclusión a la que llega "en una interpretación adecuada de ambas remisiones». No sabemos cuál pueda ser esa interpretación "adecuada» de la legalidad que, desde luego, no coincide necesariamente con la interpretación dominante de los preceptos concernidos. 
demos que resulta lícito mantener la aplicabilidad, al menos por analogía, del régimen de invalidez previsto para los actos administrativos.

b) Parece que nuestro autor trata de evitar la consecuencia que acabamos de establecer diciendo que no hay conexiones entre la regulación de los vicios de los actos administrativos y la de los reglamentos, dado que se establecen separadamente. Lo cual es cierto, aunque la distancia entre ambas regulaciones tampoco constituye un foso, como prueba su regulación conjunta en la LPA'58: dentro del título III («Actuación administrativa»), capítulo II («Actos en general»), sección $3 .^{a}$ ( «Invalidez»), llegando la proximidad a la inclusión en el mismo artículo de los supuestos de nulidad de pleno derecho, ciertamente aquí, ya distinguiendo en dos párrafos sucesivos, entre actos (art. 47.1) y reglamentos (art. 47.2). Contrariamente, por tanto, a lo que sostiene Fernández Salmerón, se aprecian claras conexiones entre el régimen de invalidez de los actos administrativos y el de los reglamentos, hasta el punto de que en algunas posiciones doctrinales que enseguida examinaremos se ha reivindicado el concepto común de actos o actuación de la Administración para los dos productos de la voluntad administrativa. Sin necesidad ahora de entrar en esa cuestión, lo que sí resulta claro es que el más completo régimen de invalidez de los actos administrativos podría servirnos para solucionar las lagunas advertidas en la regulación correspondiente a la invalidez de los reglamentos.

c) Adicionalmente, mantiene el autor que la nulidad de pleno derecho por violación de los arts. 23-27 LRJ'57 comprendía algunos trámites formales, lo que al parecer determinaría que la infracción del procedimiento de elaboración de reglamentos establecido en los arts. 129-132 LPA'58 hubiera de ser también calificada como vicio de nulidad de pleno derecho, al igual que venía haciendo la jurisprudencia en los casos de ausencia del dictamen del Consejo de Estado previsto en la legislación de este órgano consultivo. Enunciado que tampoco podemos compartir, pues siendo cierto el punto de partida, es decir, aceptando que en los arts. 23-27 LRJ'57 se contenían algunas exigencias formales, no entendemos cómo se puede sostener que las mismas comprenden todos los requisitos de forma y procedimiento establecidos en otras leyes, tanto anteriores como posteriores a la LRJ'57. La opción del legislador por el sistema de lista, que, reiteramos, es el seguido al establecer las infracciones de la legalidad determinantes de la nulidad de pleno derecho de los reglamentos, conlleva la posibilidad, evidente en nuestro caso, de que la enumeración no sea completa. El ejemplo de la variada doctrina relativa a la calificación de la ausencia del dictamen del Consejo de Estado, trámite que no está explícitamente previsto en la legislación general de régimen jurídico y de procedimiento administrativo, demuestra precisamente el carácter parcial o incompleto de la lista de vicios de nulidad de pleno derecho correspondiente a las infracciones de los arts. 23-27 LRJ'5725.

d) Pasando ya al examen crítico de los «argumentos dogmáticos» que expone Fernández Salmerón, hemos de empezar subrayando que el punto de partida y en buena medida el razonamiento sostenido bajo esa cobertura pretendidamente dogmática, no es sino una reproducción del argumento hecho valer por García de Enterría que anteriormente hemos rechazado, sobre la supuesta derogación de la ley por el reglamento que infringe un trámite previsto en la misma. A la cita del maestro se añade ahora la apreciación de Fernández Salmerón de que «parece razonable que la sanción que el ordenamiento jurídico reserva con carácter general a los reglamentos ilegales sea la de nulidad radical». La razonabilidad encontrada por el autor deriva de constatar que la acción para hacer valer la nulidad de pleno derecho es imprescriptible, no pudiendo nunca el acto nulo ni ser consentido por el afectado ni ser sanado de ninguna manera. Por nuestra parte, dando por reproducida aquí la discrepancia con el original argumento de la derogación, hemos de resaltar que nuestro autor parece querer deducir la naturaleza de una institución, no de los efectos que derivan de ésta, que sería lo pertinente, sino de los que el mismo autor quiere atribuirle. Es decir, se está haciendo supuesto de la cuestión, pues se da por probado el mismo objeto del debate al mantener que todo vicio del reglamento es de nulidad de pleno derecho. Eso es lo que habría de demostrarse, resultando indiferente para la consideración dogmática de la institución las preferencias personales de los autores.

e) Insiste Fernández Salmerón en el planteamiento anterior llegando a afirmar que la inobservancia por el reglamento de un trámite previsto en la ley equivaldría en todo caso, si no a una derogación total de la ley, sí a una derogación parcial de la misma: «la derogación no se produce de modo permanente, sino sólo puntual, al modo como podría hacerlo un acto administrativo cuyo contenido fuese contrario a una norma jurídica cualquiera». Derogación que el autor identifica más exactamente con la negación de los fines que la ley persigue al establecer la correspondiente regla de procedimiento incumplida, pues «aun siendo pun-

25 Sobre las distintas valoraciones de la omisión de la consulta preceptiva del Consejo de Estado en la doctrina del propio Consejo de Estado, la jurisprudencia del TS y la doctrina científica, véase G. GARCÍA ÁLVAREZ (1997), Función consultiva y procedimiento (Régimen de los dictámenes del Consejo de Estado), Valencia: Tirant lo Blanch (págs. 50-56). 
tual la vulneración de las disposiciones sobre el procedimiento, el desconocimiento de los fines asignados por éstas a dichos trámites sí queda perpetuado en el ordenamiento». En fin, es una manera de explicar los vicios de la actuación administrativa que puede resultar poética, pero que no refleja la realidad. Y ello no ya por la constatación jurídica de que la norma incumplida sigue vigente aunque se haya incumplido en un caso, sino porque la evocadora referencia a una derogación de hecho de la ley parece que, aun en el lenguaje coloquial, requeriría identificar un incumplimiento persistente de la misma. Por lo demás, los ejemplos que el autor proporciona de infracciones de particular gravedad del procedimiento de elaboración de reglamentos, podrían constituir vicios de nulidad de pleno derecho por aplicación analógica de la regla que así lo establece para los actos administrativos que prescindan total y absolutamente del procedimiento legalmente establecido, supuesto que en la jurisprudencia se identifica con la omisión de trámites esenciales del procedimiento.

Un tanto paradójicamente, Fernández Salmerón termina afirmando sobre sus propias argumentaciones en defensa de la nulidad de pleno derecho de todo vicio del reglamento: "Que estas consideraciones no deban extenderse a todos los trámites procedimentales es una cuestión que deberá modificar el legislador futuro». Es decir, el mismo autor parece reconocer que la interpretación que está defendiendo lleva a consecuencias demasiado estrictas ${ }^{26}$.

Como estamos viendo, en su planteamiento original la tesis unitaria fue un criterio doctrinal derivado de un determinado entendimiento de la ley. La nulidad de pleno derecho, que, en la redacción de la norma, se refería a las vulneraciones materiales de las leyes (LRJ'57), fue interpretada como aplicable también a las infracciones formales de un procedimiento establecido con posterioridad (LPA'58).

En realidad, de cara al razonamiento que estamos siguiendo, sería indiferente estimar que la literalidad de la norma incluía los vicios de tipo adjetivo, pues lo importante es subrayar que, en la óptica de la tesis unitaria, nos encontramos exclusivamente ante una cuestión hermenéutica sobre la letra de la ley. No hay elementos dogmáticos directamente implicados o, mejor dicho, si los hay, no se hacen valer por la partidarios de esta postura. No está en juego la esencia de la potestad reglamentaria, porque ningún aspecto determinante de su naturaleza jurídica resulta afectado. Al menos, tras el análisis que acabamos de hacer, puede afirmarse que ninguno de los autores que han sostenido la tesis unitaria ha ofrecido un argumento de peso que permita considerar la nulidad de pleno derecho como una exigencia connatural a la potestad reglamentaria. Los razonamientos desarrollados en tal sentido se muestran finalmente como criterios de oportunidad sobre la pureza del ordenamiento jurídico, sobre la trascendencia del procedimiento administrativo o sobre otros aspectos, cuya función termina siendo siempre la de apoyar o enfatizar el entendimiento unitario de la norma jurídica. En definitiva, el importante problema del alcance de los vicios de los reglamentos surgió y, según vamos a ver, en buena medida se mantiene todavía, simplemente como un problema de interpretación del derecho positivo, sin perjuicio de que puedan considerarse también algunos aspectos dogmáticos.

\section{LA TESIS GRADUAL: VICIOS NO INVALIDANTES, DE ANULABILIDAD Y DE NULIDAD DE PLENO DERECHO EN LOS REGLAMENTOS}

Vamos a estudiar a continuación el surgimiento y consolidación de la tesis gradual bajo la vigencia de la LRJ'57 y la LPA'58. Inicialmente, entre los autores que la sostuvieron no encontramos argumentos dogmáticos de peso, sino más bien rechazo de los fundamentos empleados de contrario y asimismo entendimiento de que la literalidad de las normas excluye la genérica consideración de todo vicio del reglamento como nulidad de pleno derecho. De nuevo, por tanto, la cuestión se ceñía a los términos en los que ha de ser interpretado el texto legal.

No obstante, la tesis gradual va a contar con el apoyo de la labor paulatina de la jurisprudencia que tópicamente, partiendo del estudio y resolución de casos concretos, fue alumbrando la doctrina. En verdad, la tesis gradual, al contrario de la unitaria, no fue una postura previa ni de la doctrina ni de la magistratura, sino la síntesis de una casuística, la respuesta a las necesidades de ponderación entre bienes jurídicos que

26 En igual línea de dudas sobre el dogma de la nulidad de pleno derecho de todo vicio de los reglamentos, el autor destaca los matices de la jurisprudencia constitucional sobre el procedimiento administrativo de elaboración de las leyes (M. FERNÁNDEZ SALMERÓN, 2002: 216-221) y también las dificultades para el pleno control jurisdiccional de los reglamentos en el ordenamiento italiano, que responde fundamentalmente con técnicas de inaplicación del reglamento ilegal (M. FERNÁNDEZ SALMERÓN, 2002: 91-145), lo que no parece corresponderse con la nulidad de pleno derecho de todo vicio del reglamento. 
se habían planteado ante los tribunales. Sólo en la última formulación doctrinal de esta tesis encontraremos ya un verdadero fundamento dogmático para la gradualidad.

El primer autor que rechazó la tesis unitaria fue F. Garrido Falla, aunque debo decir que ninguno de los razonamientos que esboza me parece convincente ${ }^{27}$ :

a) Sostiene en primer lugar que si todo vicio de un reglamento fuera de nulidad de pleno derecho, no cabría invocar el efecto de acto firme y consentido, de manera que en cualquier momento cabría recurrir los reglamentos ilegales, consecuencia que alteraría el sistema de plazos legalmente previsto para la impugnación de reglamentos. En realidad, la incongruencia se daría tanto en relación con los reglamentos como con los actos administrativos, pues ambos están sujetos en la legislación jurisdiccional a plazos de impugnación que dejan de aplicarse cuando se ejerce la acción de nulidad imprescriptible.

b) En segundo término, para el autor, la redacción del art. 47.2 LPA'58 estableciendo la nulidad de pleno derecho se explicaría por estar dirigida a los actos de ejecución del reglamento, que podrían ser impugnados en cualquier momento. Planteamiento que parece correcto entendido como posibilidad de emplear el recurso indirecto contra reglamentos, pero que no evita considerar que éste habrá de ajustarse a los plazos de impugnación del acto administrativo recurrido, plazos que si transcurren determinan la firmeza del acto, según ya se establecía en el art. 120 LPA'58.

Más consistencia creo que tienen los razonamientos de R. Entrena Cuesta, quien alega que los reglamentos no se sujetan sólo a los requisitos que les afectan como actos normativos, sino también a los establecidos para los actos administrativos, pues todos ellos son actos jurídicos de la Administración ${ }^{28}$. Planteamiento con el que parece coincidir J. L. Villar Palasí cuando afirmaba escuetamente que la impugnación de los reglamentos había de fundarse en los arts. 47 y 48 LPA'58, pues ambos preceptos se refieren «tanto a actos como a normas» ${ }^{29}$.

En todo caso, según ya hemos indicado, la tesis gradual ha de ser especialmente considerada como el resultado de la jurisprudencia que fue formándose tras la LPA'58, cuya vigencia se mantuvo hasta la LPAC'92, aunque ha de tenerse en cuenta que su aplicación por los tribunales, debido especialmente al retraso del TS, se prolongó hasta 1999. Esa jurisprudencia ha sido objeto en la doctrina de valoraciones generales y también de exposiciones detalladas que sistematizan las sentencias relativas a los diferentes vicios formales de los reglamentos. En este trabajo emplearemos esas referencias, sin perjuicio de destacar algunos casos judiciales de especial significado.

En los años inmediatamente posteriores a la LPA'58, la jurisprudencia comenzó por afirmar el carácter obligatorio de las normas reguladoras del procedimiento de elaboración de reglamentos ${ }^{30}$. Enseguida, sin embargo, algunos trámites fueron objeto de interpretaciones flexibles, llegando a estimarse innecesaria su observancia cuando el reglamento fuera reproducción de otro anterior o si contenía variantes únicamente en aspectos no fundamentales ${ }^{31}$.

En la línea exigente, cabría incluso citar algún caso en el que llegó a sostenerse la tesis unitaria. Así, en la STS de 3 febrero 1968, se consideró que el procedimiento de elaboración de reglamentos era «requisito esencial para su validez, incurriendo en nulidad siempre que la disposición de carácter general infrinja otra norma de superior jerarquía, tanto por su contenido como por no ajustarse al procedimiento previsto para su elaboración» ${ }^{32}$.

27 F. GARRIDO FALLA (1963: 78-80)

28 R. ENTRENA CUESTA (1965), Curso de Derecho Administrativo, Madrid: Tecnos (págs. 124-125).

29 J. L. VILLAR PALASí (1968), Derecho Administrativo. Introducción y teoría de las normas, Madrid: Facultad de Derecho de la Universidad Complutense (pág. 401).

30 J. A. SANTAMARÍA PASTOR (1988), Fundamentos de Derecho Administrativo, Madrid: Centro de Estudios Ramón Areces (págs. 804-805) citaba en tal sentido las SSTS de 26 de diciembre de 1961 (Aranzadi, 4387), 3 de junio de 1967 (Aranzadi (Aranzadi, 2576), 3 de febrero de 1968 (Aranzadi, 806), 18 de octubre de 1968 (Aranzadi, 4394), 24 de octubre de 1970 (Aranzadi, 4155 ) y 8 de marzo de 1973 (Aranzadi, 1172).

31 J. A. SANTAMARÍA PASTOR (1988: 804-805) citaba para esa postura las SSTS de 26 de enero de 1960 (Aranzadi, 142), 27 de diciembre de 1962 (Aranzadi (Aranzadi, 4833), 26 de septiembre de 1963 (Aranzadi, 3970), 9 de marzo de 1964 (Aranzadi, 1177) y 6 de julio de 1983 (Aranzadi, 3820). Según el mismo autor, esta flexibilización jurisprudencial era el efecto perverso del frecuente incumplimiento por la Administración de las reglas del procedimiento de elaboración de los reglamentos; situación de incumplimiento administrativo que, a su vez, podía tener las siguientes causas: la falta de adecuado detalle normativo de los arts. 129-132 LPA'58, la poca utilidad de algunos de los trámites allí previstos, la conveniencia incluso de evitar presiones sobre los órganos competentes y la imprevisión con la que normalmente se planteaba la redacción urgente de muchos textos reglamentarios.

32 Esa STS de 3 de febrero de 1968 (Aranzadi, 806), ponente M. CRUZ CUENCA, se enfrentaba a un caso realmente extremo, en el que el procedimiento de elaboración del reglamento, «lejos de haberse acreditado cumplido, procede estimar absolutamente omitido», concurriendo la circunstancia de que "los documentos infructuosamente reclamados a instancia de los recurrentes, no han 
Sin embargo, unos años después, en la STS de 17 junio 1974, se llegó a conclusiones muy diferentes al analizar frontalmente «el polémico tema del tratamiento de las irregularidades formales de las disposiciones reglamentarias» ${ }^{33}$. En la ponencia de J. Arozamena Sierra encontramos, por fin, verdaderos fundamentos de la tesis gradual:

a) En primer lugar, se hace valer el argumento derivado de la consideración de los textos legales en su contexto normativo, destacando que la tesis de la nulidad de pleno derecho no tiene, en la literalidad del art. 41 LOE'67 y en los arts. 28 LRJ'57 y 47.2 LPA'58, una previa justificación, «pues estos preceptos propiamente defienden la vigencia de la jerarquía normativa a la que sirven con la técnica de la nulidad absoluta», de manera que a la sanción rigurosa de la nulidad absoluta sólo debe acudirse ante disposiciones que "en su contenido normativo son contrarias a las leyes o que significan, por lo que es materia objeto de su regulación, una invasión de atribuciones legislativas». Se rechaza, por tanto, considerar que el reglamento elaborado con vulneración del procedimiento legalmente previsto constituya infracción de la ley en el sentido del art. 28 LRJ'57, precepto que «se refiere al plano de los contenidos normativos».

b) En segundo término, se destaca la violación del principio de proporcionalidad que conllevaría «la tesis de la sanción extrema de la nulidad absoluta en todo caso de vicio de procedimiento», pues ello supondría "un tratamiento igualitario de toda infracción», tratamiento que rompería con «la proporcionalidad entre la vulneración y la sanción legal» al introducir en el sistema de defensa del orden jurídico "una equiparación en situaciones que se presentan como muy distintas y reclaman una valoración diferente». En consecuencia, los vicios del procedimiento comprenden una escala que va "desde la leve infracción constitutiva de mera irregularidad hasta los extremos de omisión sustancial del procedimiento, con situaciones intermedias variadas», constatación que, en definitiva, justifica un distinto tratamiento de los vicios de forma y procedimiento atendiendo a las técnicas de la irregularidad, la anulabilidad y la nulidad absoluta que se establecen en los arts. 47.1.c) y 48.2 LPA'58, cuyas soluciones son «extensivas al tratamiento de los vicios de procedimiento en la elaboración de disposiciones generales» ${ }^{34}$.

Todavía bajo la vigencia de la LRJ'57 y la LPA'58, algunos autores empezaron a expresar dudas o reservas en relación con la tesis unitaria ${ }^{35}$. En todo caso, un completo tratamiento de la cuestión fue el de G. Doménech Pascual, publicado tras la LPAC'92 aunque todavía ceñido a la interpretación jurisprudencial

sido aportados por la Administración» (cdo. 4). La sentencia fue oportunamente destacada en apoyo de su tesis por E. GARCíA DE ENTERRÍA (1970: 14).

33 STS de 17 de junio de 1974 (Aranzadi, 2847), ponente J. AROZAMENA SIERRA, en especial, considerandos 3 y 4.

34 Tenemos, así, rigurosamente afirmada la tesis gradual en una sentencia que J. A. SANTAMARÍA PASTOR (1989), "El procedimiento de elaboración de los reglamentos", en J. A. SANTAMARÍA PASTOR y L. PAREJO ALFONSO (dirs.), Derecho Administrativo: la jurisprudencia del Tribunal Supremo, Madrid: Centro de Estudios Ramón Areces (págs. 84-85) empieza considerando como «la construcción argumental más simple, pero también la más sólida y elaborada para justificar la irrelevancia de las infracciones procedimentales en la materia», aunque a continuación matiza que la argumentación le parece «ingeniosa, pero de escasa solidez». Vaya, una tesis sólida pero no mucho, pues el autor estima que equiparar el régimen de defectos formales de los reglamentos al de los actos administrativos "constituye un apriorismo indemostrado y erróneo», ya que "aplicar criterios espiritualistas y antiformalistas a los vicios de forma es equivocado», dado que "en el plano de la potestad normativa el procedimiento posee una importancia funcional equiparable, si no superior, al contenido». Se reitera, en consecuencia, por este autor el criterio doctrinal que viene propugnando el entendimiento unitario de toda infracción de la legalidad como determinante de la nulidad de pleno derecho, añadiéndose ahora la inquietante apreciación de que el procedimiento pudiera tener una importancia superior al contenido. En todo caso, estas críticas no hicieron mella en la jurisprudencia, que siguió con los planteamientos graduales según nos informa el mismo autor, quien citaba en tal sentido una larga serie jurisprudencial integrada por las SSTS de 2 de octubre de 1975 (Aranzadi, 3349 ), 17 de enero de 1977 (Aranzadi, 148 ), 28 de marzo de 1977 (Aranzadi, 1446), 27 de octubre de 1978 (Aranzadi, 3403), 12 de diciembre de 1978 (Aranzadi de 1979, 801 ), 20 de junio de 1979 (Aranzadi, 2423), 9 de julio de 1980 (Aranzadi, 3011), 23 de marzo de 1981 (Aranzadi, 857$), 21$ de diciembre de 1981 (Aranzadi, 5436), 8 de junio de 1982 (Aranzadi, 4776), 29 de septiembre de 1983 (Aranzadi, 4406 ), 24 de octubre de 1984 (Aranzadi, 5144), 30 de noviembre de 1984 (Aranzadi, 6560), 20 de diciembre de 1984 (Aranzadi, 6162) y 15 de mayo de 1985 (Aranzadi, 1616).

35 R. PARADA VÁZQUEZ (1989: 64 y 67), aunque consideraba mayoritaria la opinión de que la invalidez de los reglamentos lo es siempre en su grado máximo, mantenía, sin embargo, como ya hemos indicado, que "esos pretendidos efectos radicales no se compaginan con el mantenimiento de la validez de los actos dictados en aplicación del reglamento ilegal, tal y como establece el art. 120 LPA'58». A. GALLEGO ANABITARTE y A. de MARCOS FERNÁNDEZ (1990), Derecho Administrativo l: materiales, Madrid (págs. 80-82) constataban la existencia de distintos matices en la jurisprudencia sobre la inobservancia del procedimiento de elaboración de reglamentos en función de la trascendencia real de la omisión de cada trámite en el caso analizado. L. COSCULLUELA MONTANER (1989), Manual de Derecho Administrativo, Madrid, Civitas (pág. 142) sostenía que el art. 28 LRJ'56 no recogía los vicios del procedimiento de elaboración de los reglamentos, informando de que la doctrina los incluye también como supuesto de nulidad de pleno derecho, "aunque la jurisprudencia los ha considerado en algunas ocasiones como vicios de anulabilidad». J. A. LÓPEZ PELLICER (1991), Lecciones de Derecho Administrativo, Murcia: PPU, vol. I-1 (págs.184-185) daba cuenta de la opinión doctrinal y sobre todo de la jurisprudencia que ponderaba las infracciones formales de los reglamentos admitiendo que puedan ser determinantes de la anulabilidad o incluso no determinar la invalidez de los mismos. 
dominante conforme a la LPA'58 ${ }^{36}$. Por eso puede sostener el autor que el dogma de la nulidad de pleno derecho de los reglamentos no se corresponde con la jurisprudencia, donde se admiten también supuestos de anulabilidad e irregularidades no invalidantes.

Resumiendo ahora su pormenorizado análisis sobre las sentencias dictadas a lo largo de la historia por los tribunales contencioso-administrativos, cabría ofrecer las siguientes conclusiones:

a) Al establecerse la jurisdicción delegada con el sistema mixto de 1888 y después con la judicialización de 1904, los reglamentos ilegales eran inaplicados exclusivamente por vicios de contenido, de incompetencia o de falta de publicación, sin incluir por tanto los vicios de procedimiento ${ }^{37}$.

b) Bajo la LJ'56, si bien en una primera etapa el TS se mostró favorable a inaplicar reglamentos con vicios de procedimiento consistentes en la falta de dictámenes e informes preceptivos ${ }^{38}$, luego rechazó la posibilidad de aducir vicios del procedimiento en el recurso indirecto por considerar «que no producen la nulidad de pleno derecho», salvo en los supuestos de incompetencia manifiesta o falta absoluta de procedimiento previstos para los actos administrativos ${ }^{39}$.

c) En los supuestos del recurso directo contra reglamentos previsto desde la LJ'56, la jurisprudencia se muestra rigurosa con las infracciones sustantivas, que considera siempre determinantes de nulidad de pleno derecho, mientras que para otros vicios aplica las reglas de invalidez de los actos administrativos ${ }^{40}$.

Junto al estudio detallado y creativo de la jurisprudencia, ofrece también G. Doménech Pascual una exposición dogmática sobre los fundamentos de la invalidez de los reglamentos, que presenta como el producto de una tensión entre principios contrapuestos ${ }^{41}$.

De una parte, el principio de legalidad exige que el ordenamiento establezca sanciones para el caso de incumplimiento de las normas jurídicas aplicables que, en el caso de los reglamentos, son todas las de superior rango. En tal sentido, la invalidez es una sanción que, sin embargo, admite grados diferentes, dado que las infracciones de la legalidad pueden ser de distinta gravedad.

36 Se explica esta aparente falta de sintonía temporal por el hecho de que, como ya hemos indicado, la jurisprudencia sobre los vicios de los reglamentos ajustada a la LRJ'57 y la LPA'58 se prolongó hasta el año 1999, debido al retraso de los asuntos en el TS. Pues bien, el cambio de jurisprudencia que, como más adelante veremos, se produjo en la aplicación de la LPAC'92 no llega a recogerse en la monografía de G. DOMÉNECH PASCUAL (2002), que en su origen fue una tesis doctoral defendida el 16 de julio de 1999.

37 Cita G. DOMÉNECH PASCUAL (2002: 62 y 67-69) en tal sentido, ya antes de la Ley Jurisdiccional de 1888 , las SSTS de 27 de febrero de 1874 y 21 de mayo de 1878, y después las SST Contencioso de 13 de diciembre de 1890, 28 de febrero de 1895,27 de mayo de 1895, 14 de octubre de 1895, 14 de mayo de 1897 y 9 de octubre de 1897, así como más adelante las SSTS de 15 de enero de 1907, 21 de junio de 1913, 5 de mayo de 1914, 3 de junio de 1916, 2 de octubre de 1916,18 de febrero de 1930 y otras.

38 Cita G. DOMÉNECH PASCUAL (2002: 70-71): por falta del dictamen preceptivo del Consejo de Estado, las SSTS de 12 de noviembre de 1962 (Aranzadi, 4111), 9 de febrero de 1963 (Aranzadi, 300), 7 de enero de 1964 (Aranzadi, 47 ); por falta de informe de la correspondiente Secretaría General Técnica, la STS de 8 de febrero de 1989 (Aranzadi, 990); y por falta de evaluación económica y financiera del coste de los servicios, la STS de 12 de marzo de 1997 (Aranzadi, 1788).

39 Según G. DOMÉNECH PASCUAL (2002: 71-73), la doctrina se inaugura con la STS de 23 de junio de 1973 (Aranzadi, 2731 ), donde se afirma que «al combatir los actos de aplicación individual de las disposiciones de carácter general no cabe aducir las supuestas irregularidades del procedimiento seguido para dictarlas, por cuanto se trata de vicios que no producen la nulidad de pleno derecho conforme al art. 47 LPA'58 y sí tan sólo la posible anulación a través del recurso contencioso-administrativo directo», postura que se reitera en SSTS de 23 de septiembre de 1977 (Aranzadi, 3540), 9 de enero de 1997 (Aranzadi, 2379) y muchas otras. Más exactamente, se precisa en la jurisprudencia que los vicios de procedimiento del reglamento únicamente determinan la nulidad de pleno derecho cuando encajan en el supuesto previsto para los actos administrativos de falta total y absoluta del procedimiento: SSTS de 24 de marzo de 1987 (Aranzadi, 3805), 3 de noviembre de 1986 (Aranzadi, 7735), 23 de mayo de 1988 (Aranzadi, 3918) y otras. Las razones que se esgrimen son las de seguridad jurídica, conservación del ordenamiento e incluso las dificultades prácticas que para un tribunal entraña, en el recurso indirecto, verificar el cumplimiento del procedimiento de elaboración de los reglamentos.

40 G. DOMÉNECH PASCUAL (2002: 112-113 y 116-124) sitúa en la ya citada STS de 17 de junio de 1974 (Aranzadi 2847 ) la primera ocasión en la que la jurisprudencia hizo explícitas las razones determinantes de la aplicación del régimen de invalidez de los actos administrativos a los vicios de procedimiento de los reglamentos. Explica nuestro autor que, en la aplicación de este criterio, la jurisprudencia puede parecer contradictoria porque frecuentemente emplea la palabra nulidad no como sinónimo de nulidad de pleno derecho, sino como equivalente a invalidez; en realidad, el TS sólo emplea la distinción entre nulidad de pleno derecho y anulabilidad cuando la considera relevante para resolver el caso. Hay incluso supuestos de irregularidades no invalidantes como los siguientes: la omisión del trámite de reparto del proyecto de reglamento a los ministros en SSTS de 28 de marzo de 1977 (Aranzadi, 1446 ), 21 de febrero de 1979 (Aranzadi, 775), 13 de diciembre de 1980 (Aranzadi, 4631), 3 de febrero de 1988 (Aranzadi, 651 ), 16 de junio de 1993 (Aranzadi, 4457) y 23 de abril de 1997 (Aranzadi, 3363); la falta de aprobación del proyecto por el ministro de Administraciones Públicas en SSTS de 17 de junio de 1970 (Aranzadi, 3133), y 3 de febrero de 1988 (Aranzadi, 651); la omisión de la tabla de vigencias en SSTS de 17 de junio de 1974 (Aranzadi, 2847), 28 de marzo de 1977 (Aranzadi, 1446), 10 de mayo de 1979 (Aranzadi, 3185 ), 11 de noviembre de 1981 (Aranzadi, 4169), 10 de marzo de 1982 (Aranzadi, 1245), 25 de abril de 1984 (Aranzadi, 2013), 6 de mayo de 1986 (Aranzadi, 3047), 29 de mayo de 1996 (Aranzadi, 4449), 20 de enero de 1998 (Aranzadi, 910) y otras.

41 G. DOMÉNECH PASCUAL (2002: 211-245); en buena medida, aplica aquí el autor la metodología establecida por M. BELADÍEZ ROJO (1994), Validez y eficacia de los actos administrativos, Madrid: Marcial Pons (págs. 44-47) al tratar de la invalidez de los actos administrativos. 
Pero de otra parte, la validez del reglamento ilegal puede ser sustentada con arreglo a los siguientes principios: a) el principio de conservación, que cabría imponer si, pese a la infracción de la legalidad, se satisfacen todos los fines que la norma pretendía alcanzar, conformando soluciones que incluso se advierten en la misma legislación de procedimiento administrativo cuando regula los supuestos de irregularidades no invalidantes, subsanación, conservación de trámites y de partes no viciadas, conversión e interpretación conforme a la legalidad; $b$ ) el principio de seguridad jurídica, que exige la estabilidad de las relaciones jurídicas, siendo esencial la certidumbre que proporcionan las normas jurídicas, también las de rango reglamentario, debido a su apariencia y presunción de validez, de manera que la invalidez de las mismas ha de procurar no lesionar la confianza legítimamente depositada en la aplicación de un reglamento; y c) el principio de proporcionalidad, del que deriva la necesidad de que las decisiones públicas sean idóneas para el fin perseguido, generen el menor número de desventajas posible y produzcan los mayores beneficios, elementos que permiten ponderar, siempre en el marco de los fines establecidos por la norma superior, los costes y beneficios jurídicos implicados en el mantenimiento del reglamento viciado ${ }^{42}$.

A partir de los anteriores premisas dogmáticas, en sucesivos capítulos, el autor, manejando críticamente la doctrina, la jurisprudencia y el derecho comparado, irá construyendo una completa teoría de la invalidez de los reglamentos: causas, extensión, consecuencias sobre las situaciones jurídicas, posibilidades de convalidación y conversión. En definitiva, el trabajo de Doménech Pascual nos proporciona una sólida racionalidad para la jurisprudencia que, bajo la LPA'58, había ido alumbrando la escala de los grados de invalidez de los reglamentos. La cuestión que ahora se nos plantea es la de si tal racionalidad ha sido quebrada por la más reciente legislación del procedimiento administrativo común.

\section{LA CONTINUIDAD NORMATIVA EN LA VIGENTE REGULACIÓN LEGAL DE LOS VICIOS DE LOS REGLAMENTOS}

El anterior régimen legal de los vicios de los reglamentos fue paulatinamente sustituido por la nueva legalidad democrática ${ }^{43}$. La regulación que concretamente nos interesa se estableció, primero, en el art. 62.2 LPAC'92 y, después, reproduciendo exactamente la misma redacción sin ninguna variante, en el vigente art. 47.2 LPAC'15:

«También serán nulas de pleno derecho las disposiciones administrativas que vulneren la Constitución, las leyes u otras disposiciones administrativas de rango superior, las que regulen materias reservadas a la ley, y las que establezcan la retroactividad de disposiciones sancionadoras no favorables o restrictivas de derechos individuales.».

Con respecto a las anteriores previsiones normativas (arts. 28 LRJ'57 y 47.2 LPA'58), cabe destacar la coincidencia en incluir el régimen de los vicios de los reglamentos en el mismo artículo que regula los supuestos de nulidad de pleno derecho de los actos administrativos. El precepto se inicia con el adverbio «también», quizá indicativo de que se están estableciendo, para las disposiciones generales, supuestos de nulidad de pleno derecho adicionales a los previstos para los actos administrativos.

La diferencia más llamativa entre ambos conjuntos de normas consiste en lo siguiente: a) en los arts. 23-27 LRJ'57 se incluía una lista de vicios determinantes de la nulidad de pleno derecho de los reglamentos, que comprendía las violaciones de la jerarquía normativa, las infracciones de competencia y rango, las vulneraciones de la legalidad y de las materias reservadas a la ley, y particularmente la inobservancia de las explícitas prohibiciones de establecer penas, tributos o cargas de todo tipo); b) en cambio, en el art. 62.2

42 Cabe subrayar que una de las premisas de la argumentación desarrollada por el autor es el detallado estudio sobre la formación y evolución del dogma de la nulidad de pleno derecho de los reglamentos en el ordenamiento alemán. Así, G. DOMÉNECH PASCUAL (2002: 127-128) explica como el dogma nació vinculado a la técnica de la inaplicación, dada la imposibilidad inicial de impugnar los reglamentos en vía jurisdiccional. No obstante, ya desde el principio el dogma sólo se aplicaba a vicios de contenido, competencia y publicación, pues las reglas de procedimiento de elaboración de los reglamentos no existían hasta su introducción para ordenanzas locales y planes urbanísticos. En la actualidad, la jurisprudencia del Tribunal Contencioso-Administrativo Federal descarta que toda infracción del procedimiento de elaboración de reglamentos tenga la consecuencia de la nulidad de pleno derecho, habiéndose establecido, además, por el legislador mecanismos que reducen el alcance de los vicios de procedimiento en los planes de urbanismo.

43 Cronológicamente, el proceso fue el siguiente: a) la Constitución de 1978 derogó expresamente todas las leyes fundamentales franquistas, incluido por tanto el régimen establecido en el art. 41 LOE'67; b) la LPAC'92 derogó la mayor parte de la LPA'58; y c) la LOG'97 completó el desplazamiento de la LRJ'57. 
LPAC'92 y en el vigente art. 47.2 LPAC'15, aunque también se sigue el sistema de lista, los supuestos de nulidad de pleno derecho se refieren genéricamente a cualquier vulneración constitucional, legal y de los reglamentos de rango superior, añadiéndose la referencia a dos contenidos constitucionales especialmente destacados como son las materias reservadas a la ley y el principio de irretroactividad in peius establecido en el art. 9.3 de la Constitución ${ }^{44}$.

Vemos pues que de la segunda enumeración legal han desaparecido las referencias a las infracciones de competencia y rango, y a las específicas prohibiciones de establecer penas, tributos o cargas de todo tipo. Ello no supone, claro está, que ahora se permita a los reglamentos establecer penas, tributos o cargas, materias sobre las que inciden conocidas reservas constitucionales de ley (arts. 25.1 y $35.3 \mathrm{CE}$ ), además de prohibirse explícitamente en el art. 128.2 LPAC'15 ${ }^{45}$. La diferencia relevante pudiera referirse entonces a las infracciones de competencia y rango, que antes se recogían explícitamente en los arts. 24-25 LRJ'57 (a los que se remitía el art. 47.2 LPA'58 por intermedio del art. 28 LRJ'57) y que ahora no se incluyen expresamente en el art. 47.2 LPAC'15 (ni antes en el art. 62.2 LPAC'92); ¿podrían estarlo implícitamente o por remisión?

Cabe responder afirmativamente a esa pregunta si consideramos que el legislador de 1992-2015 sigue empleando el sistema de lista para identificar los específicos supuestos de nulidad de pleno derecho de los reglamentos. En lugar de establecer que cualquier infracción del orden jurídico hace nulo de pleno derecho al reglamento, se enumeran las infracciones determinantes de la nulidad de pleno derecho ${ }^{46}$. Lo lógico es entender que algo queda fuera de la relación, pues hemos de suponer que el legislador no enumeraría los vicios de nulidad de pleno derecho si pudiera incluirlos en una fórmula general ${ }^{47}$. Entendimiento éste con el cual, adicionalmente, se daría significado específico, como ya hemos indicado, al también con el que se inicia el precepto, haciéndolo equivalente a un además de, de manera que, junto a los supuestos de nulidad de pleno derecho enumerados en el 47.1, para los reglamentos habría que incluir también los contenidos en el art. 47.2 LPAC'15 (preceptos coincidentes como sabemos con los arts. 62.1 y 62.2 LPAC'92).

En consecuencia, los reglamentos son nulos de pleno derecho, entre otros casos, cuando hayan sido dictados con incompetencia manifiesta, o prescindiendo del procedimiento o de las reglas esenciales de los órganos colegiados [art. 47.1.b) y e) LPAC'15]. Supuestos estos que sin ningún esfuerzo conceptual permiten incluir las infracciones de competencia y rango que se preveían en los arts. 24-25 LRJ'57, preceptos en los que esencialmente se imponía que las disposiciones generales del Consejo de Ministros adoptasen el rango de decretos y las de los ministros el de órdenes. También ahora esas mismas infracciones serían determinantes de la nulidad de pleno derecho al implicar la incompetencia manifiesta, la falta absoluta de procedimiento y/o la infracción esencial del régimen de órganos colegiados. Por tanto, a la pregunta formulada hemos de responder diciendo que, de manera explícita, implícita o por remisión, la lista de 1992-2015 es coincidente con la de 1957-58.

En definitiva, apreciamos que la mayor condensación de la vigente enumeración legal de vicios de nulidad de pleno derecho de los reglamentos no impide identificar todos los supuestos que se contenían en la más detallada enumeración legal anterior. Son dos listas iguales en sus efectos, diseñadas ambas con

44 La fórmula genérica de los arts. 62.2 LPAC'92 y 47.2 LPAC'15 se parece a la del art. 41 LOE'67, aunque con la notable diferencia de que la también genérica nulidad prevista en éste, se transforma explícitamente en nulidad de pleno derecho en los nuevos preceptos.

45 Efectivamente, en el art. 128.2 LPAC'15, dentro del título que contiene el régimen de la potestad reglamentaria, se relacionan algunos límites o prohibiciones sin coincidir completamente con la lista del art. 47.2 de la misma LPAC'15, aunque sin establecer explícitamente el grado de invalidez correspondiente a su infracción. Por lo que ahora interesa, entre las novedades con respecto al último precepto citado, se establece en el primero que los reglamentos «no podrán tipificar delitos, faltas o infracciones administrativas, establecer penas o sanciones, así como tributos, exacciones parafiscales $u$ otras cargas o prestaciones personales o patrimoniales de carácter público».

46 El legislador de 1992 tuvo incluso la oportunidad de adoptar la fórmula general, pues en el proceso de elaboración de la LPAC'92, el Grupo Popular presentó las enmiendas 487 del Congreso y 419 del Senado para que la nulidad de pleno derecho se refiriera a "las disposiciones administrativas contrarias al ordenamiento jurídico», con objeto de "no dejar fuera otras ilegalidades no mencionadas en el texto del proyecto». Sin embargo, las enmiendas no fueron aceptadas, manteniéndose la enumeración de los supuestos determinantes de la nulidad de pleno derecho. Proporciona esta información M. FERNÁNDEZ SALMERÓN (2002: 213, en nota).

47 Así sucede con los vicios de anulabilidad de los actos de la Administración, que vienen refiriéndose legalmente a «cualquier infracción del ordenamiento jurídico, incluso la desviación de poder» en las sucesivas regulaciones del procedimiento administrativo (arts. 48.1 LPA'58, 63.1 LPAC'92 y 48.1 LPAC'15), las cuales toman la fórmula de la legislación contencioso-administrativa (art. 83.2 LJ'56, reproducido en el vigente art. 70.2 LJ'98). La específica referencia a la desviación de poder no convierte a la genérica mención legal en una lista de vicios determinantes de la anulabilidad, pues tiene el objetivo de destacar una de las infracciones del ordenamiento jurídico, la que deriva de la infracción, no ya de la literalidad de las normas, sino de los fines que éstas persiguen, aclaración que, en la década de 1950, fue novedosa y que las leyes vigentes conservan probablemente por considerarla ya tradicional. 
la mismos contenidos, sin que exista, por tanto, ninguna razón de tipo semántico para dar un significado diferente a las violaciones de la legalidad. Si éstas comprendieran tanto las sustantivas como las adjetivas, carecería de sentido práctico el resto de la enumeración contenida en el art. 47.2 LPAC'15, habiendo pues de concluirse que las únicas vulneraciones de la legalidad determinantes de la nulidad de pleno derecho de los reglamentos, en la dicción de la norma, siguen siendo únicamente las de tipo material o sustantivo.

\section{EL CAMBIO INADVERTIDO A LA JURISPRUDENCIA UNITARIA Y LA ALARMA DOCTRINAL}

Las nuevas leyes de procedimiento administrativo, tanto la de 1992 como la vigente de 2015, han sido objeto de variadas críticas procedentes especialmente de la academia y el foro. En ellas se ha puesto de relieve la escasa novedad de sus contenidos y la incertidumbre de algunas de sus previsiones, de manera que se ha llegado a considerar preferible haber continuado con las leyes derogadas, si acaso introduciendo en ellas algunas reformas. Una de las consecuencias más temibles de estos vendavales legislativos deriva de la circunstancia de que muchos actores jurídicos tienden a olvidar o descuidar los precedentes, planteándose la aplicación de las normas como si éstas fueran verdaderamente nuevas. En el caso de las leyes que nos ocupan, ese efecto perverso ha podido verse agravado por la publicidad institucional encaminada a magnificar los logros del ejecutivo promotor de las respectivas reformas ${ }^{48}$.

El caso es que tras la LPAC'92 la jurisprudencia dio un completo vuelco al régimen de invalidez de los reglamentos. El art. 62.2 LPAC'92 fue objeto de una interpretación diametralmente opuesta a la que venía prevaleciendo sobre el art. 47.2 LPA'58, sin suscitarse siquiera la mención de la jurisprudencia anterior ni, en absoluto, la posible equivalencia entre el contenido de ambos preceptos. Y eso que, como hemos recordado, la jurisprudencia precedente se había prolongado debido al retraso de los asuntos en sede jurisdiccional. En este punto, pues, la nueva legislación supuso la plena ruptura con el pasado. Así, donde antes prevalecía una elaborada y razonada jurisprudencia gradual, determinante de soluciones ponderadas en cuanto al alcance de la invalidez de los reglamentos, a partir de la LPAC'92 dio lugar a la vigente jurisprudencia unitaria que considera todo vicio de un reglamento determinante de su nulidad de pleno derecho.

En realidad, las palabras objeto de hermenéuticas tan divergentes eran prácticamente iguales, pues en todos los textos legales se trataba de interpretar si la vulneración de las leyes calificada con la nulidad de pleno derecho comprendía únicamente las infracciones sustantivas o también las procedimentales. Bajo la LPA'58, una larga evolución jurisprudencial había llevado a asumir, para los vicios de procedimiento de los reglamentos, la misma escala de invalidez de los actos administrativos, desde las irregularidades no invalidantes a los supuestos de anulabilidad y, en último extremo, de nulidad de pleno derecho cuando se había prescindido gravemente del procedimiento de elaboración. Después, conforme a la LPAC'92, que aquí coincide exactamente con la vigente LPAC'15, directamente, sin ninguna mención de la jurisprudencia anterior, el TS ha interpretado las mismas palabras («las disposiciones contrarias a las leyes» en 1958 y "las disposiciones que vulneren las leyes» en 1992-2015) de manera muy distinta al incluir en ellas las infracciones sustantivas y las adjetivas, y calificar a todas como nulas de pleno derecho.

Claro, si el intérprete exclusivamente considera la letra de la norma en vigor, sin atender a sus antecedentes, ni a su contexto, ni a los principios que inciden en su alcance, es lógico que entienda comprendida en la vulneración de las leyes las infracciones materiales y formales de las mismas. Pero en tal caso se violan las tradicionales reglas hermenéuticas establecidas en nuestra legislación (interpretación literal, contextual, histórica y finalista) y también el principio constitucional de igualdad ante la ley, que exige que todo cambio en la interpretación de la norma por los tribunales se haga considerando y contraponiendo expresamente los fundamentos de la antigua y la nueva doctrina jurisprudencial ${ }^{49}$. Nada de eso se ha hecho en nuestro caso.

Al parecer, desde la STS de 17 diciembre 1999 viene afirmándose de manera dominante en la jurisprudencia que «el grado de invalidez de las disposiciones generales es único: la nulidad absoluta, radical o de pleno dere-

48 La franquista LPA'58 fue acompañada de la retórica de la «reforma administrativa», la socialista LPAC'92 se ofreció como producto depurado de la «modernización administrativa» y la popular LPAC'15 ha inaugurado la "reforma virtual de las administraciones públicas». El legislador siempre presenta sus elaboraciones como si antes de ellas no hubiera nada establecido en la materia o lo que había no mereciera ninguna atención.

49 Vénse, por ejemplo, las SSTC 25/1999, de 8 de marzo (FJ 5), 117/2004, de 12 de julio (FJ 3), 27/2006, de 30 de enero (FJ 3), 105/2009, de 4 de mayo (FJ 5) y 7/2015, de 22 de enero (FJ 3). 
cho, ya se trate de un vicio de forma o sustantivo» ${ }^{50}$. Lo que antes era objeto de matices ha pasado a ser, en la misma jurisprudencia, una verdad tan evidente que no precisa de ninguna demostración. En una reciente exposición, se citaba en tal sentido la referencia de la STS de 23 septiembre 2003 a «la abundante doctrinal jurisprudencial» que establece "que la nulidad de pleno de las disposiciones de carácter general es siempre radical o de pleno derecho», reiterándose en la STS 2 marzo 2016 que, en el caso del reglamento, "se trata de una nulidad de pleno derecho, independientemente de si son vicios de forma o de fondo los que han determinado la anulación» ${ }^{51}$.

En consecuencia, no cabe aplicar a los reglamentos las previsiones sobre conservación de actos y trámites ni la convalidación, al ser instrumentos establecidos para los actos administrativos. Según se afirma en la STS de 7 septiembre 2016: "la misma naturaleza normativa hace inviable la aplicación de los principios de conservación y de convalidación», siendo incluso inviable la aplicación analógica de tales instituciones debido a "las diferencias sustanciales entre el acto y la norma»" 2 .

En esta situación, si bien continúan manifestándose opiniones favorables a la nulidad de pleno derecho $^{53}$, paralelamente empiezan a sonar con fuerza las voces doctrinales que muestran su disconformidad o al menos su insatisfacción con la rígida solución a la que se ha llegado sobre el alcance de la invalidez de los reglamentos.

M. Sánchez Morón sostiene que «no toda infracción legal depara los mismos efectos», de manera que "hay que distinguir los vicios de fondo de los defectos de forma del reglamento». Si en cuanto a los primeros no hay duda de que su consecuencia es la nulidad de pleno derecho, en cambio los segundos pueden consistir en irregularidades no invalidantes, limitándose en todo caso por la jurisprudencia la posibilidad de su impugnación a la vía del recurso directo ${ }^{54}$.

F. López Menudo señala que lo razonable es entender que los vicios formales de los reglamentos pueden ser calificados según su gravedad, como nulos, anulables o meras irregularidades no invalidantes ${ }^{55}$.

M. Rebollo Puig considera que el art. 47.2 LPAC'15 (igual que antes el art. 62.2 LPAC'92) no enumera todos los posibles vicios de los reglamentos, como los de competencia, desviación de poder, vulneración de principios generales, defectos de procedimiento o retrasos administrativos, por lo que «no considera falta de fundamento» la solución consistente en aplicar a los vicios no enumerados de los reglamentos el régimen de nulidades previsto para los actos administrativos ${ }^{56}$.

J. L. Martínez López-Muñiz explica que la consideración de todo vicio del reglamento como de nulidad de pleno derecho deriva de no haber identificado los elementos comunes con el acto administrativo, los cua-

50 STS 8147/1999, de 17 de diciembre, ponente A. GOTA LOSADA, FD 3. Conviene tener en cuenta que esta sentencia está dictada en un caso en el que todavía era aplicable la LPA'58, de manera que se acentúa el significado del cambio jurisprudencial inadvertido.

51 Véase C. TOLOSA TRIBIÑO (2017: 54-55), quien informa también de alguna pervivencia aislada de la jurisprudencia anterior: así, en la STS de 28 de marzo de 2008, planteada la infracción del plazo de 30 días para la práctica de información pública de un reglamento (plan parcial), plazo que se había rebajado por la Administración a 15 días, aunque con prórroga posterior de 15 días más, se estimó «evidente que tal modo de proceder no representa una falta total y absoluta de procedimiento que genere la nulidad radical prevista en el art. 62.1.e) LPAC'92, sino un supuesto de anulabilidad contemplado en el art. 63.2 de la misma ley, que, para ser apreciada, requiere la indefensión de los interesados, la que en este caso no se da»; y en la STS de 17 de julio de 2009 la declaración de nulidad de pleno derecho de un reglamento por falta del dictamen preceptivo del Consejo de Estado se hizo al considerar que se había prescindido absolutamente del procedimiento, en aplicación del supuesto de nulidad de pleno derecho previsto para los actos administrativos en el art. 62.1.e) LPAC'92 [actual art. 47.1.e) LPAC'15]; sin embargo, reacciona expresamente contra este criterio la STS de 6 de mayo de 2015, que rechaza retrotraer el procedimiento al momento en que se produjo la vulneración del trámite de información pública, pues «no nos encontramos ante un acto administrativo, sino ante la elaboración de una disposición de carácter general, por lo que la infracción del trámite de información pública determina su nulidad».

52 Véase C. TOLOSA TRIBIÑO (2017: 56), quien cita en el mismo sentido SSTS de 13 de diciembre de 2001, de 3 de enero de 2002, de 10 de mayo de 2011, de 31 de mayo de 2011 y de 28 de septiembre de 2012, entre otras. No obstante, en la STS 278/2017, de 17 de febrero, ponente R. FERNÁNDEZ VALVERDE, se admite la existencia de un defecto formal-la ausencia de un «resumen ejecutivo» del plan general, exigido en el art. 25.3 TRLS de 2015 como requisito de transparencia-, pero se señala que la sentencia recurrida "acierta cuando no impone la sanción de la nulidad de pleno derecho en el supuesto de autos, pues, como en toda nulidad relativa, la concurrencia de la misma dependerá de la acreditada indefensión del recurrente», añadiendo el TS, para justificar la inexistencia de indefensión, el conocimiento que el recurrente demuestra en su demanda de los contenidos del plan (FD 7).

53 Véanse, entre otros: L. PAREJO ALFONSO (2003), Derecho Administrativo, Barcelona: Ariel (pág. 349), S. MARTíN-RETORTILLO (2007), Instituciones de Derecho Administrativo, Madrid: Civitas (pág. 202), G. FERNÁNDEZ FARRERES (2012), Sistema de Derecho Administrativo, Madrid: Civitas (pág. 248) y J. M. TRAYTER JIMÉNEZ (2015), Derecho Administrativo. Parte general, 2. ${ }^{a}$ ed., Barcelona: Atelier (pág. 137).

54 M. SÁNCHEZ MORÓN (2005), Derecho Administrativo: parte general, Madrid: Tecnos (pág. 213).

55 F. LÓPEZ MENUDO (2014), "Las fuentes del Derecho Administrativo", en C. BARRERO RODRÍGUEZ (ed.), Lecciones de Derecho Administrativo. Parte general, Madrid: Tecnos, págs. 77-111 (pág. 109).

56 M. REBOllo PUIG (2016), Derecho Administrativo I, Madrid: Tecnos (págs. 253-254). 
les permiten aplicar el gradual régimen de invalidez de los actos a los supuestos no previstos explícitamente para los reglamentos ${ }^{57}$.

L. Martín Rebollo, si bien estima que los reglamentos viciados son nulos de pleno derecho, al plantearse la posible retroacción de efectos de la declaración de nulidad señala que «es una consecuencia radical que debe ser matizada», porque «llevada a sus extremos conduce al caos», concluyendo, como ya hemos indicado, que «si se conservan actos de aplicación de un reglamento nulo es evidente que la nulidad queda un tanto matizada en sus perfiles teóricos» ${ }^{58}$.

Incluso autores que están en el origen y los fundamentos de la tesis unitaria, a la vista de algunos planteamientos jurisprudenciales, introducen importantes matices.

Así, en E. García de Enterría y T. R. Fernández Rodríguez, se hace una muy necesaria llamada a "evitar eventuales excesos», considerando que "cuando se trate de vicios de procedimiento es imprescindible comprobar antes de declarar la nulidad absoluta del reglamento al que afectan la efectiva trascendencia de los mismos», observaciones que "son particularmente pertinentes en relación a los planes de ordenación urbana», pues "hay que evitar caer en una sacralización de las formas» ${ }^{59}$.

Por su parte, M. Fernández Salmerón, en línea con las dudas que ya había expresado anteriormente, estima "lógica» la tendencia, que a su juicio subyace en la jurisprudencia, a considerar que "únicamente los vicios de contenido, junto a los de falta de publicación e incompetencia, son auténticamente constitutivos de la nulidad radical de la disposición, mientras que las deficiencias en la tramitación del procedimiento darían lugar a la mera anulabilidad de ésta, cuando no sean determinantes de meras irregularidades no invalidantes» ${ }^{60}$.

\section{RECAPITULACIÓN: LOS FUNDAMENTOS DE LA VUELTA A LA TESIS GRADUAL DE LOS VICIOS DE LOS REGLAMENTOS}

Tras nuestro recorrido por las vicisitudes interpretativas de los preceptos relativos a los vicios de los reglamentos, me parece que se impone concluir, ante todo, que su aplicación descontextualizada nos está llevando a consecuencias difícilmente admisibles. El problema no estriba en interpretar gramaticalmente la expresión "serán nulas de pleno derecho las disposiciones administrativas que vulneren ... las leyes» contenida en el art. 47.2 LPAC'15. Si tal fuera el caso, toda discusión estaría de más, pues es claro que las leyes se vulneran cuando no se observa cualquiera de sus contenidos, tanto de tipo material como de índole formal. Lo que sucede es que no es ni puede ser ése el supuesto que nos está ocupando, ya que aquí el sentido propio y aislado de las palabras chirría cuando se pone en contacto con los restantes elementos que hemos de considerar en la interpretación de las leyes atendiendo al mandato del art. 3.1 del Código Civil:

"Las normas se interpretarán según el sentido propio de sus palabras, en relación con el contexto, los antecedentes históricos y legislativos, y la realidad social del tiempo en que han de ser aplicadas, atendiendo fundamentalmente al espíritu y finalidad de aquéllas.».

Por tanto, el objeto de nuestra interpretación es, no una frase ni mucho menos una palabra, sino un precepto, el art. 47.2 LPAC'15, que transcrito íntegramente dice:

"También serán nulas de pleno derecho las disposiciones administrativas que vulneren la Constitución, las leyes u otras disposiciones administrativas de rango superior, las que regulen materias reservadas a la ley, y las que establezcan la retroactividad de disposiciones sancionadoras no favorables o restrictivas de derechos individuales.».

a) La interpretación contextual de la norma nos obliga considerar, en primer término, la opción legal por el sistema de lista. La vulneración de las leyes y reglamentos de rango superior es uno más de los supuestos

57 J. L. MARTíNEZ LÓPEZ-MUÑIZ (2016), “La elaboración de los reglamentos”, en F. LÓPEZ MENUDO (dir.), Innovaciones en el procedimiento administrativo común y el régimen jurídico del sector público, Universidad de Sevilla, págs. 307-344 (págs. 340-342).

58 L. MARTÍN REBOLLO (2017: 406-407).

59 E. GARCÍA DE ENTERRÍA y T. R. FERNÁNDEZ RODRÍGUEZ (2017), Curso de Derecho Administrativo, vol. I, Madrid:

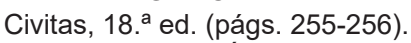

${ }^{60}$ M. FERNÁNDEZ SALMERÓN (2017), "La potestad reglamentaria. El procedimiento de elaboración de los reglamentos", en E. GAMERO CASADO (dir.), Tratado de procedimiento administrativo común y régimen jurídico básico del sector público, Valencia: Tirant lo Blanch, t. II, págs. 2.483-2.549 (págs. 2.544-2.547). 
de nulidad de pleno derecho de los reglamentos que se enumeran en la norma, donde se recogen los vicios que hemos de suponer lógicamente más graves de los reglamentos, al conllevar la opción por el sistema de lista que algo se deja fuera de la misma. En consecuencia, ha de propiciarse un entendimiento de la norma que dé sentido a la relación de vicios en ella contenida, objetivo que se frustraría si el supuesto referido a la vulneración de las leyes comprendiera aspectos sustantivos y adjetivos, pues en tal caso nada, ninguna infracción quedaría fuera del precepto. $Y$ si ningún vicio hubiera de haber quedado fuera del supuesto de hecho normativo, ¿no tendría que concluirse que el legislador habría optado por una fórmula omnicomprensiva? Algo así como "serán nulas de pleno derecho las disposiciones generales que vulneren de cualquier manera lo establecido en normas de rango superior».

b) Siguiendo con la interpretación contextual, hemos de subrayar la conexión con el régimen de invalidez del acto administrativo. Por más que la potestad reglamentaria sea distinta de la resolutoria, no puede desconocerse, como está haciendo la jurisprudencia, que la invalidez de actos y reglamentos se regula en el mismo capítulo de la ley e incluso en el mismo artículo, según sucede precisamente con los supuestos de nulidad de pleno derecho, que se establecen sucesivamente en los dos párrafos del art. 47 LPAC'15. La conexión llega hasta el extremo de que la enumeración legal de los vicios de nulidad de pleno derecho de los reglamentos da comienzo con el adverbio «también», que perfectamente puede ser interpretado como equivalente a "además de», con la consecuencia de que los reglamentos serían nulos de pleno derecho en los casos enunciados en los dos párrafos del precepto, también en los referidos a los actos de la Administración.

c) La interpretación histórica del precepto confirma la hermenéutica anterior, pues, como hemos visto, el art. 47.2 LPAC'15 es la reproducción textual del art. 62.2 LPAC'92 que, a su vez, fue un resumen de los supuestos a los que se remitió el art. 47.2 LPA'58, esto es, los recogidos en los arts. 23-27 LRJ'57. Ese es el origen del vicio de los reglamentos consistente en vulnerar las leyes, que se formuló explícitamente en el art. 26 LRJ'57: «La Administración no podrá dictar disposiciones contrarias a las leyes». El supuesto normativo sólo podía interpretarse como integrando las infracciones materiales de las leyes, ya que entonces no se había regulado todavía el procedimiento de elaboración de los reglamentos. Obsérvese que cuando ese procedimiento se establece en la LPA'58, la propia ley cuida de circunscribir los supuestos de nulidad de pleno derecho de los reglamentos a «los casos previstos en el art. 28 LRJ'57». Es el arrastre de la fórmula legal el que determina los problemas interpretativos que nos ocupan. Problemas que se agudizan cuando los aplicadores jurídicos prescinden de los antecedentes y asumen las nuevas regulaciones como si aparecieran de la nada: en efecto, como nos consta, la más reciente jurisprudencia se ha formado prescindiendo por completo de la anterior, desconociendo, así, los fundamentos de la tradicional tesis gradual que tan laboriosamente se había gestado.

d) Por último, el criterio de interpretación finalista nos lleva a conectar con los fundamentos dogmáticos de la materia que, a lo largo del estudio, únicamente hemos podido encontrar en la vieja y clarificadora ponencia del magistrado Arozamena Sierra (1974) y en el documentado y sólido estudio de Doménech Pascual (2002). No vamos a repetir aquí argumentos que ya han quedado suficientemente expuestos: principio de legalidad frente a principios de conservación, seguridad y proporcionalidad; puntos de equilibrio, escala de soluciones, gradualidad de los vicios. Tales son los planteamientos propios de nuestro ordenamiento jurídico que permiten establecer unos perfiles claros del problema que nos ocupa. Por añadidura, esas construcciones de la dogmática jurídico-administrativa van encontrando plena correspondencia con los estudios de Derecho Comparado que acreditan la quiebra del dogma de la nulidad de pleno derecho de los reglamentos ilegales y también con la flexibilidad que se advierte en el Derecho Constitucional al fijar los efectos de las sentencias que declaran la inconstitucionalidad de las leyes ${ }^{61}$.

61 Para el Derecho italiano véase M. FERNÁNDEZ SALMERÓN (2002: 91-145) y sobre el alemán, G. DOMÉNECH PASCUAL (2002: 127-178); un resumen de ambos ordenamientos en la materia en C. TOLOSA TRIBIÑO (2017: 57). En la jurisprudencia constitucional simplemente destacaré ahora las SSTC 194/2004, de 10 de noviembre y 35/2005, de 17 de febrero, que, tras anular por razones competenciales leyes de protección de espacios naturales, mantienen, sin embargo, su vigencia hasta la aprobación de un nuevo régimen de protección; también las SSTC 164/2013, de 26 de septiembre, 164/2014, de 7 de octubre y 13/2015, de 5 de febrero, que difieren por un año la efectividad de la declaración de nulidad de leyes aprobadas sin observar trámites establecidos en el bloque de la constitucionalidad (informes autonómicos previstos sobre ciertas materias en los Estatutos de Canarias y Aragón). 